\title{
FORTIFIED VILLAGES OF MEDIAEVAL BYZANTIUM: TOWN OR VILLAGE?
}

\author{
Yury Ya. Vin \\ Institute of World History, Russian Academy of Sciences, Moscow, Russian Federation
}

\begin{abstract}
The search for a model rural settlement - "village" is the common position in interpretation of the problem on the "fortified villages" of Mediaeval Byzantium. On the one hand, the multiformity of the settlement's types in the Byzantine Middle Ages is conditioned by climatic and local natural specificities. On the other hand, the patterns of rural settlement are predetermined by the social and economic structure and development of all the other sides of life of habitants of the village, including a dwelling. The tasks of the defence of population foreordain a necessary of construction of fortresses ("kastra") and their deployment into defensive system. It quite corresponds to the processes, developed in many south regions of Mediaeval Europe, where the building of fortifications, transmuting the village into the fortress - "castrum", becomes as rule. The building of the fortresses and other fortifications in towns and rural settlements of Mediaeval Byzantium creates a trend, designating the degree of necessary defence of its habitants. This tendency makes itself felt in Late Byzantium. The guarded by walls rural settlements here were not unique. The "pyrgoi" and so named "dwelling towers" were built everywhere, these served as refuges for villagers in the ordeals of the war years. The appellation "pyrgos" turned into synonym of the designation of the rural settlement, as a landlord's state, and a substitute of term "chorion". The "pyrgoi" appeared practically as "keypoints" of every description of the territories of large landownings, the passed ways and the households arranged there. The system of fortifications as a defence of whole region was deployed in Byzantine country, where the rural settlement has significant position. The article consists of the Introduction ("Introduction. The Village and key Problems of its Studying"), three parts ("The fortified Settlement", "The rural Fortifications", "The Pyrgos") and the part "The Results and Conclusion. The Common Trends", where the main problems are examined, touching the study of the Mediaeval Byzantine village, pyrgoi and common regularities of fortification of Late Byzantine village.
\end{abstract}

Key words: the mediaeval Byzantine village, rural fortification, fortress, pyrgos, dwelling tower.

Citation. Vin Yu.Ya. Fortified Villages of Mediaeval Byzantium: Town or Village? Vestnik Volgogradskogo gosudarstvennogo universiteta. Seriya 4. Istoriya. Regionovedenie. Mezhdunarodnye otnosheniya [Science Journal of Volgograd State University. History. Area Studies. International Relations], 2021, vol. 26, no. 6, pp. 194-223. (in Russian). DOI: https://doi.org/10.15688/jvolsu4.2021.6.17

УДК 94«04/14»:911.373

ББК 63.3(0)4-9

Дата поступления статьи: 01.06.2021

Дата принятия статьи: 22.11.2021

\section{УКРЕПЛЕННЫЕ СЕЛА СРЕДНЕВЕКОВОЙ ВИЗАНТИИ: ГОРОД ИЛИ ДЕРЕВНЯ?}

\author{
Юрий Яковлевич Вин \\ Институт всеобщей истории РАН, г. Москва, Российская Федерация
}

\footnotetext{
Аннотация. Общим положением в освещении проблемы укрепленных сел Средневековой Византии является поиск истоков типового сельского поселения - «села». С одной стороны, византийское Средневе$\overrightarrow{\widetilde{ح}}$ ковье отличало многообразие типов селений, обусловленное климатическими и другими местными природСે ными особенностями, с другой - типологические черты сельского селения предопределяли общественный ๘. уклад и закономерности развития всех сторон жизни обитателей сел, включая жилище. Задачи защиты населения диктовали необходимость сооружения крепостей («кастра») и их развертывание в оборонительную Е систему. Это вполне отвечает процессам, происходившим в Раннее и Развитое Средневековье во многих южных регионах Европы, где возведение укреплений, по сути, превращающих село в крепость - «ка-
} 
струм», становится правилом. Строительство крепостей и иных укреплений в городах и сельских селениях Средневековой Византии становится тенденцией, обозначившей собою степень необходимой защиты для их жителей. Эта тенденция легко ощутима и в поздней Византии. Здесь огражденные оборонительными сооружениями сельские селения уже не были единичны. Повсеместно возводятся пирги или так называемые жилые башни - оборонительные постройки, служившие убежищем селянам во дни военных испытаний. Само название «пирг» становится синонимом обозначения сельского поселения, как господского имения, и, по существу, замещает термин «хорион». Пирги выступали «ключевыми точками» практически всех описаний территорий крупных землевладений и сельских населенных пунктов с ведущими к ним дорогами и расположенными там хозяйствами. В сельских местностях Византии развертывается система укреплений в качестве оборонительного рубежа целого региона, в которой могло занимать значимое положение сельское поселение. Статья состоит из Введения («Введение. Село и ключевые проблемы его изучения»), трех разделов («Укрепленные селения», «Сельские укрепления», «Пирг»), а также раздела «Результаты и Заключение. Общие закономерности», где рассматриваются основные проблемы изучения средневекового византийского села, укрепленного селения, сельских укреплений, пиргов и общие закономерности укрепления поздневизантийского села.

Ключевые слова: средневековое византийское село, сельское укрепление, крепость, пирг, жилая башня.

Цитирование. Вин Ю. Я. Укрепленные села средневековой Византии: город или деревня? // Вестник Волгоградского государственного университета. Серия 4, История. Регионоведение. Международные отношения. - 2021. - Т. 26, № 6. - C. 194-223. - DOI: https://doi.org/10.15688/jvolsu4.2021.6.17

Светлой памяти Бориса Львовича Фонкича, с самой искренней благодарностью...

...the differentiation [which], scholars have made between cities and villages, or between these two and castles, is unclear and certainly not self-evident

(...разница [которую], ученье проводят между городами и селами, или между этими двумя и замками, неясна и, конечно, не самоочевидна).

\section{Ronnie Ellenblum}

Введение. Село и ключевые проблемы его изучения. Восстановить облик средневекового села в Византии - задача нелегкая. Ведь «село», по меткому высказыванию М. Энголда, принадлежит к саморегулирующимся социальным институтам [52, р. 74]. Исследование «села» требует комплексного и дифференцированного подхода к рассмотрению отдельных сторон жизни многоликого сельского поселения. Решение этой задачи усугубляется тем, что речь идет о сельском поселении эпохи Средневековья. Сведения о нем рассеяны в огромном диапазоне разного рода источников - от актов до археологических раскопов и затрагивают самые различные аналитические аспекты, начиная с изучения жилища, служившего селянину убежищем от многих жизненных невзгод, природных и социальных факторов развития села. В центре внимания надлежит ставить проблемы типологии селения, включая способы обозначения села и его функции в системе управления и сельскохозяйственного производства. Они раскрываются в ходе анализа структуры села и складывающихся на его территории хозяйственных комплексов в их развитии и эволюции. Одновременно требуют особого освещения неразрывно связанные с указанной проблематикой оборонительные функции села, поелику вопрос защиты от вражеских нападений напрямую касается и сельских поселений, что выдвигает на передний план задачу различения городских центров и сел.

Сразу же надо подчеркнуть, что проблема дифференциации города и села - ключевая проблема всего Средневековья. Она усугубляется строительством крепостей и иных оборонительных сооружений. Феномен укрепления средневековых населенных пунктов, обусловленных защитными их функциями, захватывает и город, и деревню. Эта проблема вызывала непрестанный научный интерес многих поколений медиевистов и целого ряда ведущих византинистов, что ярко продемонстрировала предпринятая начиная с 1982 г. серия научных мероприятий, объединяемых под названием «Каструм» («Castrum») [65]. В последние десятилетия публикации результатов исследований различных аспектов развития средневекового города и деревни, как того, что их соединяет, так и их размежевания, в том числе возникновения и там, и тут долговременных оборонительных систем, 
превратились в бурный нескончаемый поток, направляющий современную медиевистику и византинистику в единое научное русло (напр., см.: [143; 90]). На общем фоне, с точки зрения автора этих строк, выделяется представленное Н. Кристи и Х. Херолд, инициаторами издания материалов двух масштабных международных научных форумов 2013 г., которые раскрывают современные научные достижения в изучении защищенных поселений раннесредневековой Европы [77]. Всесторонне изучая совокупность сопряженных с указанной темой фундаментальных научных проблем археологии и истории, их социальных и гуманитарных аспектов, названные ученые суммируют и обобщают в своем введении к опубликованному труду обнародованные авторами коллективного труда взгляды на развитие общинных структур. Они, как это ни странно может показаться на первый взгляд, занимают важнейшее место в интегрально представленных трудах, что позволяет Н. Кристи и Х. Херолд показать общие закономерности и региональную специфику не только городской, но и сельской, крестьянской общины. Касаясь различных сторон существования средневекового общинного института, начиная с первой и до последней страницы, в конечном итоге названные ученые освещают сопряженность церкви и общины под углом духовного и религиозного развития ее членов [67, p. I etc., XXXVII].

Общим положением в освещении указанных проблем является поиск истоков типового сельского поселения - «села» - в Средневековье [74, р. 26, 29-31]. Сказанное касается, в частности, и предпринятой в свое время попытки Ж. Лефора, прибегая к довольно пространному, если речь идет об определении, описанию типологических сторон жизни византийского села, определить его суть через воссоздание социокультурной альтернативы «села» (village) с присущей ему изначально «коммунальной» экономикой, с одной стороны, и «поместья» (estate), с другой стороны [107]. Между тем при рассмотрении проблемы сельского поселения Византии крайне важно учитывать широкое разнообразие природноклиматических и социально-экономических условий существования и форм жизнедеятельности селян, что непременно сказывалось на огромных различиях типологических черт сельского поселения и планов его застройки (подробнее см.: [81, esp. p. 10-15 etc.]). Одним из принципиальных различий между городом и деревней, которые равным образом касаются средневекового западноевропейского и византийского обществ, признается жилище [134, S. 278]. Правда, обстоятельному изучению поставленных проблем препятствуют трудности их разрешения применительно к Средиземноморью. Византийские исторические источники изучаемого периода, в том числе актовые и археологические материалы, содержат сведения преимущественно о домах и их утвари, которые принадлежали в основном зажиточным горожанам [97, S. 69, 191-198 u. а.; 124, p. 205-214, esp. p. 207-208]. Неказистые и бедные постройки сельских поселков средиземноморского региона время быстро уничтожало, независимо от того, были ли это дома тех, кто побогаче, или утлые хижины бедняков [50, p. 137-139]. Предохранить средневековые крестьянские жилища от разрушения не могло даже сравнительно широкое использование в Южной Европе для их постройки камня, который применялся для сооружения сельских жилых и хозяйственных построек и в материковой Греции, и на средиземноморских островах [9]. К тому же крестьянский дом обычно характеризует сравнительная простота внутреннего убранства, главным элементом которого служил скромный очаг [64, p. 34-38]. Однако скоротечность существования сельского жилища не должна стать непреодолимой препоной для выяснения статуса, структуры и разнообразных функций сельского селения. С одной стороны, византийское Средневековье отличало многообразие типов селений, обусловленное климатическими и другими местными природными особенностями, с другой - типологические черты сельского селения предопределяли общественный уклад и закономерности развития всех сторон жизни обитателей сел [21, с. 157 и дал.; 81, p. 17 etc.].

Действительно, средневековое сельское жилище в Византии, как правило, отвечало социальному положению его хозяина. В лучшем случае местом проживания сельских жителей становились выложенные из камня приземистые домики с плоской глиняной или черепичной кровлей [155, б. 272-273]. Относящихся к ним археологических находок, сколь бы они 
Ю.Я. Вин. Укрепленные села средневековой Византии: город или деревня?

не были многочисленны, в течение долгих десятилетий оказывалось все-таки недостаточно для создания полных и ясных представлений об устройстве поздневизантийского села (напр., см.: [62, S. 651-653]). Преимущественно в ход шли отдельные примеры, дававшие повод для разрозненных наблюдений и обобщений ${ }^{1}$. Сейчас это положение заметно изменилось и материалы раскопок, производимых в сельских местностях, уже позволяют судить об условиях жизни в средневековых византийских селениях с бо́льшей уверенностью в отношении скромных по своим размерам сельских жилищ, отличительной чертой которых нередко служил утрамбованный земляной пол (подробнее см.: [81, еsp. p. 37-40]). Археологические данные существенно дополняют и помогают объяснять скупые описания письменных источников, тогда как для археологов на передний план выходит умение связать результаты ежегодных раскопок с документальными свидетельствами (подробнее см., напр.: [146, S. 171-193, bes. S. 185]). Последние же подтверждают, что речь идет обыкновенно об одноэтажных строениях прямоугольной формы. И даже если их стены сложены из камня или кирпича, перекрыть их черепичной крышей могли позволить себе только крупные земельные собственники, в поместьях которых строили подобные дома наряду с жильем для зависимых от них крестьян. Предназначенные для них дома крыли камышовой или соломенной кровлей [134, S. 280 ff., bes. 287-288]. Если верить посвященной строительству сельского жилища единственной строке фольклорно-поэтического календаря, возможно несколько утрировавшего повседневные реалии, в рассматриваемую эпоху для сооружения хижины бедного селянина - каливы, сезонного приюта пастухов и сельскохозяйственных работников [81, р. 14], - требовались лишь прутья и трава. На сопровождавшем этот рассказ рисунке калива изображена в виде укрепленного на тонких столбах легкого навеса, который, очевидно, затем обносили плетенными из хворостин стенами ([75, б. 383.41-42]. Ср.: [75, б. 392]. Также см.: Константинополь. Серальская б-ка. Рукоп. гр. 35 [83]). Для беднейших крестьян это было, видимо, вполне приемлемое жилье, тогда как на Лемносе в заключительный период византийской исто- рии даже у зажиточных дворохозяев наряду с привычными для них домами упоминаются, принимая во внимание особенности местного народного диалекта, если не землянки, то

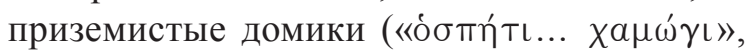

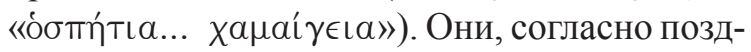
нейшей копии практика рубежа XIV-XV вв. монастыря Пантократора, находились в крепости [38, Append. 49-50, 64]. Столь низкий уровень жилых построек более чем показателен. Подобные лачуги местных крестьян становились, предположительно, лишь временным местом жительства при нападениях врагов, допустим, пиратов. На этот случай было возведено, как можно думать, и самое укрепление. Впрочем, более типичным жильем для зажиточных хозяйств в сельских местностях, как и в небольших городских пунктах, наверное, следует признать своего рода двухэтажные строения, где первый этаж или полуподвальное помещение отводилось под хозяйственные нужды, а сами обитатели таких домов занимали верхний этаж. Такие дома средневековые

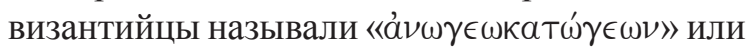
подобным образом. В частности, такие дома были построены для присельников на том же Лемносе и в крепости Коцину, и в метохе Ватопедского монастыря рядом с его «пиргом» [36, № 164.4-5; 42, № 128.41-43, 44-46], «укрепленным строением», как определяет этот термин Ж. Лефор [105, р. 100].

Укрепленные селения. Современные археологические находки свидетельствуют о том, что сельские селения поздневизантийского времени действительно бывали укреплены, что полностью соответствует общей тенденции усиления оборонительных функций населенных пунктов Балкан и Малой Азии указанного времени [99, р. 157-170, esp. p. 157-159 etc.]. По мнению М. Деккера, средневековая византийская крепость обычно была цитаделью (stronghold), откуда осуществлялось управление небольшим округом, который мог включать не только городские центры или даже большие города, но окрестные села. В этом плане, судя по наблюдениям ученого, средневековый укрепленный район схож с ранневизантийскими крепостями [73, p. 78, 92]. Их ведущую роль и в управлении, и в обороне прямо или косвенно отображает ранневизантийское законодательство, унаследованное 


\section{ВИЗАНТИЙСКОЕ ОБЩЕСТВО И ГОСУДАРСТВО}

Средневековьем (напр., см.: D.XLII.22.001. Pr. [68] - B.A.LX.32.001.Pr. [60]). Средневековые византийцы, надо сказать, заимствовали греческие рецепции понятия «крепость»

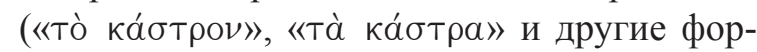
мы) из латыни ли, или романских языков, где соответствующая терминология обрела региональную специфику (подробнее см.: [67, P. XXVII-XXIX]; также см.: [146, S. 185 u. a.]). Для Византии, судя по некоторым высказанным учеными суждениям, специфику реципированного понятия «то̀ ка́бтроv» выражало, прежде всего, подчинение крепостей мощи государственной власти, с одной стороны [109, p. 202-204], с другой - их экономические функции, которые реализовывались благодаря тому, что под защиту крепостных стен стекались земледельцы, и византийские крепости нередко обрастали посадами [122, p. 133 etc.].

С точки зрения Ж. Лефора и его коллег, средневековые византийские города и села, включая укрепленные населенные пункты, с X-XI вв. образовывали «сети» («reseau») в виде небольших агломераций $[110$, p. 15; 106 , p. 68-69; 115, p. 87-88]. По мнению Ж. Лефора, термин «кастрон» применим исключительно для обозначения городских укреплений, что вполне согласуется с общепринятым взглядом на средневековый византийский город, и указанный термин не приложим к описаниям наподобие выражения «укрепленное село» ([105, p. 100]; также см.: [72, p. 393]). Вместе с тем ведущие специалисты, как это видно на примере труда Ш. Джерстел, говорят об укрепленных селах («fortified villages»), которые получали обозначение «кастра», иначе говоря, «кастрон» или «кастро» ([81, p. 20]; также см.: [81, p. 34, 36, 37 etc., 40]). И в данном рассказе о средневековой Греции, который продолжает Ш. Джерстел, речь идет уже не о сохраненных временем останках укреплений селений, нередко городских центров позднеантичного или ранневизантийского происхождения, - они также не остаются без внимания специалиста (напр., см.: [81, p. 15-16]), - а о вновь возводимых оборонительных сооружениях [81, p. 36]. Важно, что подобные «крепости», которые многие исследователи идентифицируют не иначе, как городские центры (the fortified cities) (напр., см.: [99, p. 157, esp. p. 163 etc.]), Ш. Джерстел называет «укрепленное поселе- ние» («fortified settlement») и подчеркивает, что в поздневизантийский период истории такие селения превращались в хорошо населенные опорные пункты [81, p. 33-34]. Показательно, что применительно к ним И. Кодер, отождествляя «кастрон» и «бург», использует обозначение «обнесенные каменной стеной бургоселами» («ummauerte Burgdorfer») [97, S. 66-67]. Правда, при этом возникает двусмысленность в том, всякое ли «укрепленное поселение» допустимо отождествлять с сельским, даже если условия жизни в нем сопоставимы с условиями, как пишет Ш. Джерстел, «сравниваемых общин» («comparable communities») [81, p. 21-22 etc.].

В этой связи необходимо пояснить, что поставленная проблема уходит вглубь веков истории империи и неотъемлемо соприкасается с проблемой развития в Византии средневекового города. Очевидно, следует упомянуть о том, что его история начинается после «темного» периода истории империи в VII в., когда в соответствии с концепцией, которую в последние десятилетия развивает М. Хэлдон, развертывается «культурная трансформация» Византии (подробнее см.: [84]). В последующие столетия происходит возрождение городских центров, преимущественно мелких, небольшой площади и численности населения. В условиях того времени, постоянных войн и периодических набегов неприятелей, требовалось их укрепление. Это были чаще всего укрепления нового типа: они охватывали населенный пункт стенами со всех сторон, чтобы защищать жителей города, иногда вместе с предместьями. Их население и обитатели окрестных сел во дни нападений врагов искали спасения за стенами сооруженных тогда крепостей («кастра»), как отныне обозначались средневековые городские центры [86, esp. p. 247-252, 255-256; 85, p. 11-12]. Иначе их историки называют, так это делает, например, Дж. Хэлдон, «укрепленными городами», «городами-крепостями» («fortified town», «fortress towns») и т. п. [86, p. 60, 113, $114,176,180,241,255]$. Как заявляет Дж. Хэлдон, термин «кастрон», получая широкое распространение в IX-X вв., прилагается к византийским городским поселениям безотносительно их физического типа [85, p. 16 etc.]. Говоря иными словами, Дж. Хэлдон подчерки- 
Ю.Я. Вин. Укрепленные села средневековой Византии: город или деревня?

вает, что в период VII-X вв. слово «кастрон» входит в повседневный язык как обозначение укрепления, воплощавшего чаяния членов общества на безопасность и спасение. В новых условиях существования термин «кастрон» противопоставлен античному «полису», как выражение новых общественных ценностей и реалий $[85$, p. 17-18]. В этот, если можно так сказать, «центральный» период византийской истории неразрывной частью местной оборонительной системы, как отмечает ученый, наряду с городскими поселениями, бывали, по сути, и села [86, p. 180, 255]. Население таковых агломераций, проживавшее, говоря словами историка, в отдельных общинах (in separate communities) или селах «в пределах стен» (within the walls), ощущало свою принадлежность к «полису» как таковому! $[86$, p. 250] Опосредованно это показывает, обращаясь к «власти предержащей», Иоанн Апокавк: и на рубеже поздневизантийского периода истории его современникам не были чужды представления предшествующих эпох o «полисе» как «оплоте». В одном из своих посланий просвещенный церковный иерарх, словно бы воспроизводя мысль своих предшественников, протестует против разрушения старинных городов: «Полисы же, каковые сами сооружены для вашей крепости, ты превращаешь в могильные курганы и срываешь их до основания...»

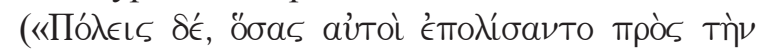

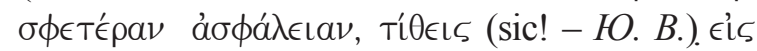

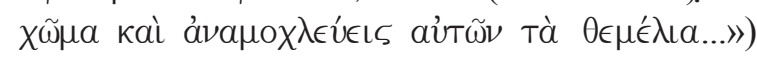
$[152$, 4. № 33. б. 116]. Как бы то ни было, в конечном счете термин «кастрон», олицетворяя, по мысли Дж. Хэлдона, социокультурную трансформацию средневекового византийского социума, прилагается к поселениям любого типа, включая крупные города и близлежащие малые населенные пункты, к которым, в надежде найти там убежище, тяготеют местные сельские общины [85, p. 21].

В самом деле, системный характер преобразований, в ходе которых на рубеже Раннего и Развитого Средневековья византийские городские центры и окружавшие их сельские селения формировали единый административный, экономический и оборонительный комплекс, косвенно подтверждает формуляр актов, где используется заключающее в себе идею некой неразрывности выражение «все

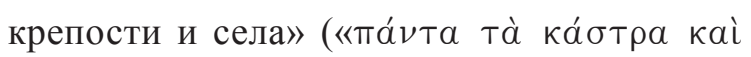

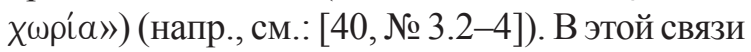
нельзя не упомянуть об одной из схолий Феодора Вальсамона к «Номоканону», приписываемого патриарху Фотию. Составитель схолии в своем атипичном виде указал на «крепости и

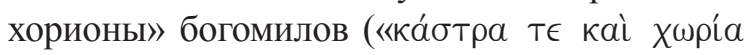

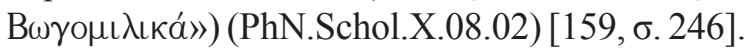
Со всей определенностью допустимо говорить о том, что богомилы расселились в окрестностях этих укреплений в целях обезопасить себя от противодействия местных властей. В свете проявлявших себя интенций укрепление сельских селений в Поздней Византии является закономерным шагом ее исторического развития, уходящего своими корнями к истокам византийского Средневековья, когда в системе административного управления ставились в один ряд «крепости» с примыкавшими к

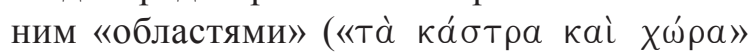
и тому подобные варианты этой формулы, включая многочисленные инверсии типа « самые разнообразные другие инварианты, подразумевающие не только военную, но и административную значимость крепостей, подкрепляемую время от времени прямыми ссылками на ранее обнародованные указы и распоряжения верховной и местной власти) ([40, № 3.2-4; 30, № 12.3; № 45.24; № 46.22; № $47.22-23$; 42, № 79.2; № 81.A.2; № 82.2; 45, № 18.13 ; 43, № 23.1-2; № 25.1-2; 32, № 19.1-2; № 22.1-2]; также см., напр.: [42, № 110.12-13, 23-24; № 125.5-6 etc.]). К сожалению, этот факт специалисты отмечают подчас лишь мимоходом (напр., см.: [6, с. 190, 233]). Между тем, практически восприняв силу византийской традиции администрирования, прямо на единство системы управления города и деревни в поздневизантийский период согласно стереотипной формуле сопоставления «крепостей и областей» («т元 $\delta \eta \lambda \omega \theta \epsilon ́ \nu \tau \omega \nu$

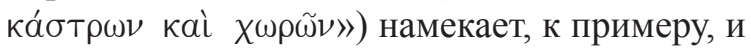
греческий хрисовул Стефана Душана 1346 г. [44, № 25.43-45 etc.]. Словом, строительство защитных укреплений неразрывно сопряжено со стародавней проблемой основных обозначений сельских селений в византийских источниках, таких как «коме» и «хорион», которые противопоставлялись обозначениям городских центров, и «полису», и «кастра»². К тому же 


\section{ВИЗАНТИЙСКОЕ ОБЩЕСТВО И ГОСУДАРСТВО}

красноречиво отождествление «Хроники» Псевдо-Франдзи «коме» и поселков городского типа («астиев»), сопровождающееся пояснением, что албанцы называют такие селения «крепостями» (ка́бтраऽ) [131, р. 530.36-38].

Так или иначе, противоречивые сведения документов подчас побуждают исследователей поднимать вопрос о критериях разграничения города и деревни, когда внешние различия между небольшими местечками и крупными селами оказывались минимальными [88, p. 200-201; 106, p. 69; 94, p. 101-104 etc., 219]. В этой связи, конечно, можно было бы напомнить о крайне упрощенном понимании вопроса со стороны Ж. Лефора и его последователей, которые в свое время пытались ранжировать провинциальные населенные пункты, город и села, опираясь на сведения о числе их жителей, занимаемой площади и торговых функциях города (подробнее см.: [126, p. 63 etc.]). В наши дни нельзя не сослаться на методологически важные размышления и замечания М. Вейку относительно роли междисциплинарного подхода к изучению различий средневекового византийского города и деревни, который бы охватывал данные исторических источников и результаты археологических раскопок. Их интегрированная оценка, как показывает в своих исследованиях названный специалист, как правило, опирается на известные интерпретационные модели. В их ряду фигурируют, в частности, такие, как определение типологической структуры и размеров селения («ядерный» и «разбросанный» тип поселения, «крупное» и «малое» селение), дихотомия «город» и «село» (или в более широком плане «город» и «деревня», «сельская местность»), дуализм природы «урбанизации» и «натурализации» («ruralisation»), соответственно «укрепленное» и «неукрепленное» селение и т. д. Хотя многие из этих общепризнанных положений, как и мнение М. Вейку о том, что в каждом отдельном случае убедительных критериев анализа отдельных сторон селений может оказаться явно недостаточно, в большой мере «тонут», К сожалению, в мишуре постмодернизма, это не становится помехой для выдвижения на передний план концепции многовековой «трансформации» селений, точнее говоря, концепции «перехода» («transition») как всеобъемлющего феномена комплексного видоизменения се- лений, которое охватывало помимо предшествующих и XI-XV столетия (подробнее см.: [145, p. 43-54, esp. p. 47-48; 147, p. 160-164, $165,203])$. При этом эмоциональные оценки исследовательницы не препятствуют весьма определенному выводу о том, что Южный Эпир VII-XI вв. демонстрирует чрезвычайно высокую гибкость организации селений, что вполне интерполируется и в отношении остальной территории Византии (подробнее см.: [145, p. 51 etc.; 147, p. 200-205]). Собственно говоря, рассматривая средневековые греческие хорионы с точки зрения уровня их экономического развития, М. Вейку высказывает со всей определенностью мысль о том, что в образованной сельскими селениями IVIX вв. «сети» (network) с VI-VII вв. и впоследствии широко распространенную характерную особенность составляли «укрепленные села» [148, p. 131 etc.]. Равным образом археолог говорит о натурализации городской экономики Византии IX-X вв., что уже тогда поставило в один ряд не только обозначения городских центров с сельскими населенными пунктами, но и их обустройство, оборонительное значение и возведение там крепостных стен, как показывают последующие наблюдения М. Вейку над различиями крепостей в странах средневековой Европы и Византии. Здесь, по убеждению специалиста, роль крепостей определялась не столько административными и социополитическими функциями, сколько развитием аграрной экономики [146, р. 184 u.a., bes. p. 188]. Итак, М. Вейку, отыскивая новые аргументы и способы выражения своей главной идеи, стремится к признанию средневековых «кастра», то есть обозначения, по мнению археолога, выходящего за пределы дуалистического понимания противопоставления «город» - «деревня», новым, «отличным» от прежнего, типом средневекового селения [147, p. 168-176, 180, 200-201, 201-202, 203-204]. Однако необходимо иметь в виду, что эта мысль сама по себе сквозит, как было показано, и в суждениях Дж. Хэлдона, развившего в своих публикациях инновационную идею предшественников и коллег о преобразовании античного и ранневизантийского полиса в средневековый «кастрон» («Von der Polis zum Kastron») ([87, S. 12 u.a.]; также см.: [85, p. 12; 84, esp. p. 104, 459-461]; там же указана ос- 
Ю.Я. Вин. Укрепленные села средневековой Византии: город или деревня?

новная литература). И в исследованиях других специалистов вполне ясно выражена научная позиция, согласно которой главный результат социокультурной трансформации средневекового селения заключался в обновлении его статуса, когда идентификацию «город» или «село» определяли не размеры агломерации или иные факторы, а прежде всего существование укреплений (напр., см.: [117, p. 154-155 etc., 158; 95, p. 144-145]).

В определенном смысле способы обозначения статуса средневековых византийских селений весьма показательны: их самообозначения далеко не всегда оставались идентичны, а порой постоянно варьировали. Таковым предстает статус Иериссо ([139, p. 929-930]; там же указана основная литература; также см.: [126, p. 157-158; 125, p. 373-396; 113, S. 56, 58-59]). В постановлении 1239-1240 гг. местного епископа Феофила о пресечении противоправных действий жителей этого населенного пункта он последовательно назван сначала «полисом»

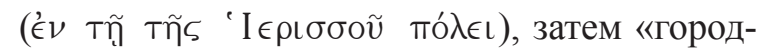
ком» (тп̃ неоднократно - «хорионом» ([41, № 14.1, 14, 37; Delimit.4-5]; также см.: [113, S. 55, 56]). При этом, конечно же, необходимо принимать во внимание тот факт, что в X в. в Иериссо существовала населенная местными жителями «крепость» [107, р. 264]. Ее неоднократно называет, рассказывая о противоборстве монастыря Колобу с афонскими насельниками из-за класмированной земли, используемой иериссиотами, в своем сообщении 942-943 гг. эпопт Фома ([39, № 5.11, 17, 25, 55-56, 62-63]; также см.: [39, № 5.18-19, 26-28, 53-54]). Крепость Иериссо не просто упоминается в целом ряде актов на протяжении более столетия, в том числе акте протопафария Симеона, утвердившего предположительно в 974 г. налоговые эземпции для париковдимосиариев, переданных Лавре Афанасия [34, № 6.8-9 etc., 13 etc.], а также договоренностей 982 г., когда жители крепости стали одной из сторон в урегулировании вопросов землепользования в ближайших окрестностях ([46, № 4, esp. № 4.19; № 5, esp. № 4.8-19]; также см.: [46, № 1.1; № 2.12-13; № 7.27-28 etc.; № 8.4-5, 6-7; № 27.8-9, 11 etc.; № 29.5, 9, 11, 71, 75, 76, 89, 91, 94; № 31.51 ; № 41.65 etc.]) и некоторых иных актов конца X - XI в. (напр., см.: [34, № 8.9-10; № 18.25-26; № 39.4

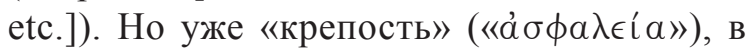
данном случае имеется в виду тип документа, епископа Иериссо Николая 1032 г. говорит о «палеокастроне» Иериссо и о стоявшей, судя по всему, неподалеку «крепости» [44, № 4.5-6, 11-12]. А в начале XII в. акт произведенного высокопоставленным чиновником, проедром и логариастом имений Сгуром, уточнения границ земельных владений в районе Иериссо, при описании границ проастия св. Святого Павла в Агиасме содержит прямое указание на топоним «Палеокастрон», тогда как далее это поземельное описание отмечает размещение в названной местности «новой крепо-

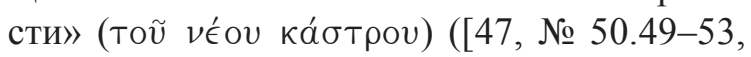
esp. № 50.50]; также см.: [47, № 53.193, 200]). Ее подразумевает, по всей вероятности, и ссылка на крепость Иериссо в практике Радоливо 1104 г., которую хотелось бы сопоставить с упоминанием топонима «Палеокастрон» в так называемом кадастре того же села, составленном в последующее время ([47, № 52.571 etc.]; о хорионе Радоливо и указанных документах подробнее см.: [13, с. 67-84; 106, р. 66-71; 104, p. 269-313]). В числе других документов по указанному поводу оправданно выделить также хрисовул Стефана Душана 1346 г., в котором сербский правитель отмечает париков, поселенных в «крепости» Иериссо [44, № 25.6]. В любом случае, даже если речь идет о топографически различных участках территории Иериссо, документы поздневизантийского времени, которые, как показано ранее, упоминают топоним «Палеокастрон», относящийся к названному селу, не оставляют сомнений в достоверности древнейших сведений о его крепостных укреплениях [48, № 70.192-193, 195-196; № 75.308-309; № 79.289, 290-291; 49, № 86.142-143, 144-145]. Это, в свою очередь, позволяет некоторым ведущим византинистам, в том числе издателям афонских актов, идентифицировать Иериссо, даже при отсутствии какой-либо атрибуции топонима в акте, заведомо и однозначно как «город», тем самым упрощая картину реального состояния известного поселения в поздневизантийский период его истории, когда Иериссо по своему статусу признано «хорионом» (напр., см.: [34, p. 401; 30, p. 327]; cp.: [37, p. 271; 42, p. 475]; также см.: [125, p. 373-396, esp. p. 374 etc.]). 


\section{ВИЗАНТИЙСКОЕ ОБЩЕСТВО И ГОСУДАРСТВО}

Впрочем, отдавая должное исследовательскому мастерству издателей афонских актов, хотелось бы выделить пример акта прота Саввы. Он, урегулируя в 1368 г. споры монахов Лавры и Ватопеда из-за владений «монастырька» рядом с Сидерокавсием, упоминает некую неназванную «крепость», которую издатели этого акта идентифицируют с укреплениями именно Иериссо! ([42, № 127.7-8]; см.: [42, р. 332])

В методологическом плане, однако, важнее признать, что еще ранее, на рубеже Раннего и Развитого Средневековья, в Византии определилось системное соотношение различных категорий городских и сельских поселений, где постепенно, на протяжении всего Средневековья, развертывалась система укреплений. Как это ни странно, что может показаться на первый взгляд, одно из очевидных проявлений системного деления населенных пунктов на типы можно обнаружить в «Типике» Григория Пакуриана, иначе называемого «Устав Петрицонского монастыря», то есть монастыря Св. Богородицы Петрициотисы (конец XI в.) (подробнее см.: [26]; там же указана основная литература). Его составитель, - предположительно, им стал сам Григорий Пакуриан ([144, p. 252.22-254.3; р. 256.4-6]; подробнее см.: [26, с. 135, 234]), - невольно указывает на ключевое значение укрепленных городских центров, к которым тяготели в экономическом, социально-политическом и административном плане окрестные села и сельские местности. В данном случае имеется в виду не только, и не столько тот факт, что составитель типика определяет местоположение вновь основанного им Петроцонского монастыря в «топотесии

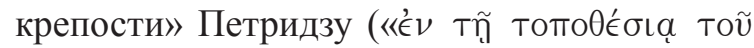
ка́бтроч») ([144, р. 98.17-18]; подробнее см.: [26, с. 122]). А ведь этот населенный пункт, как выясняется далее, был ничем иным, а, собственно говоря, «хорионом» с прилегающими к нему господскими имениями [144, p. 120.9-11 etc.]. И дело заключается вовсе не в том, что затем, характеризуя жизнь монахов в обители, составитель типика прибегает к довольно распространенному со времен Античности и Раннего Средневековья терми-

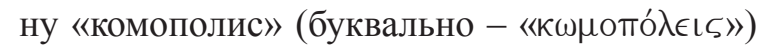
[144, p. 100.29-32]. Как бы ни пытались исследователи интерпретировать это понятие, представляя его словно бы нечто «среднее» между городом и деревней, - в частности, так высказывается вслед за своими предшественниками В. А. Арутюнова-Фиданян (подробнее см.: [26, с. 140-141]), - речь должна идти об единой агломерации городского центра и его предместьев, а не просто «большой (sizable) деревне» ([140, p. 1692]; также см.: [85, p. 1, $10 ; 120$, p. 179]) или «подобном маленькому городу селении» (a small town-like settlement) (напр., см.: [95, p. 144; 141, р. 282]). И к сказанному остается лишь прибавить, что «комополис», по словам одного из исследователей, в рамках разрабатываемой им концепции «урбанизации» ранневизантийских сел, кою также нельзя обойти молчанием, обладал «характеристиками и села, и города» («a settlement with characteristics of both a kome and a polis») [93, p. 16]. Недаром Иоанн Апокавк в своих посланиях сопоставлял «комополисы» и с «полисами», и с «комами», то есть «поселками» [152, 4. № 42, p. 138; № 79, p. 230].

На самом деле, «Типик» Григория Пакуриана, проясняя, согласно проведенному описанию границ, местоположение хориона Стенимаху, уточняет, что он вместе с другими монастырскими имениями прилегал к двум возведенным здесь крепостям [144, p. 120.2123 etc.]. В то же самое время Петрицонскому монастырю была передана крепость Ваниска вместе с водным источником, «остальными его всеми хорионами», агридиями и прочими держаниями ([144, p. 120.32-122.2]; также см.: [144, p. 248.25-26]). Что же касается хориона Прилонкий, то он принадлежал названной обители вместе «со старыми крепостями его»

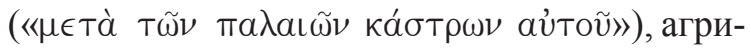
диями и иным имениями ([144, р. 126.4-7]; о хорионе Прилонкий см.: [144, р. 124.13-16]; также см.: [26, с. 24, 157]). Это упоминание «старых крепостей», коих всего во владениях Пакуриана византинисты насчитывают до шести, свидетельствует об общей тенденции к укреплению средневекового византийского села, а вновь возводимые «крепости», иначе говоря, «укрепленные поселения», как отметила А. В. Арутюнова-Фиданян, несомненно служили обороне владений Григория Пакуриана ([26, с. 29, 122]; также см.: [66, р. 202]). Бесспорным свидетельством тому служит «хрисовул об улучшениях в моих имениях, строительстве крепостей, и хорионов, и мо- 


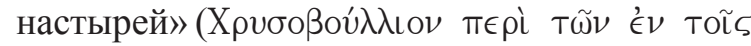

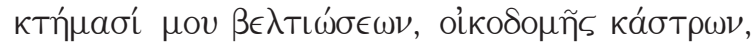

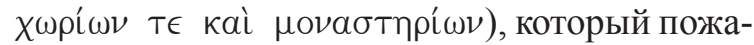
ловал Григорию Пакуриану Алексей I Комнин ([144, p. 248.27-28]; о характере «строительной деятельности» Григория Пакуриана, а также об атрибуции данного хрисовула подробнее см.: [26, с. 221]). Построенные военачальником крепости, вероятно, наравне с самими пожалованными ему хорионами, где воздвигались новые укрепления, не были крупномасштабными населенными пунктами, но они оказались вплетены в систему владений крупного собственника, став ее неразрывной частью наравне с землями, хозяйственными сооружениями и даже зависимыми крестьянами-париками [144, p. 128.18-29]. В конечном итоге составитель названного типика употребил родившуюся под его пером своего рода шаблонную градацию принадлежащих ему имений, расположенных преимущественно в селах и их окрестностях, наподобие ряда схожих формул, где выделяется особое место близлежащему укреплению:

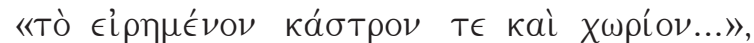

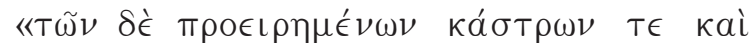

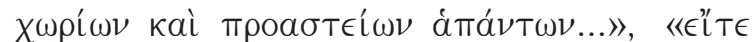

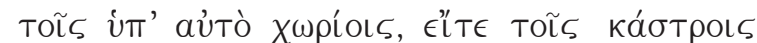

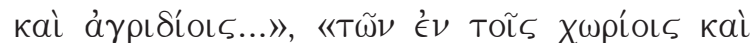

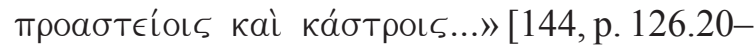
21, 25-26; p. 198.27-28; p. 208.19; p. 248.2728]. Иначе говоря, населенные пункты условно подразделялись на три категории, а именно крепости, хорионы и проастии, агридии и прочие имения.

Саму по себе отмеченную градацию нельзя считать простой фигурой речи, поскольку вырисовывающаяся из приводимых слов картина отображала реальный мир средневекового византийца, в рамках которой сельские селения оказывались соединены в единое целое с укрепленными пунктами. Достаточно сослаться на акт землеотвода 1008 г. монастырю Св. Акиндина на территории села Радохоста. Его жители, подтверждая продажу земельного участка и отказываясь от дальнейших претензий на него, удостоверили, что отводимый названному монастырю участок

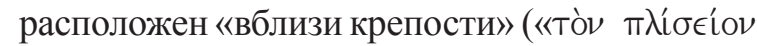
тои̃ ка̋бтрой»-sic!) [34, № 14.6-7 etc.]. Описанному примеру не противоречит также уре- гулирование в 1076-1077 гг. спора о земельном участке между жителями стоявшей неподалеку от Фессалоники крепости Адрамери и монахами лаврского метоха Перистеры. Решая вопрос о принадлежности спорного участка, представители проживавших в названной крепости эпиков, можно думать, не самого большого в этой округе поселения, признали, что парикам метоха был передан для возделывания земельный надел. Он, по всей вероятности, находился по соседству с неким упомянутым жителями крепости хорионом, атрибутировать который более точно не позволяют утраты текста составленного тогда акта ([34, № 37.4-7 etc., esp. 11.17-18 etc.]; см.: [108, p. 295]). Аналогичная ситуация предстает впоследствии, скажем, в акте 1162 г. дуки Фессалоник Иоанна Контостефана, который произвел непростое урегулирование между Лаврой Афанасия и держателем пронии Панкратием Анемы [56, p. 37-40 etc.]. Не останавливаясь на всех обстоятельствах этого урегулирования, которое затрагивало интересы поселенных в округе крепости, носившей данное местными жителями название «Весельцы» («В $\epsilon \sigma \epsilon \lambda$ Тог̃»), стратиотов и крестьян, сейчас хотелось бы отметить, что оно касалось проастия Архонтохориона, периорисм (описание границ) которого начинался у этой крепости ([34, № 64.34-36]; также см.: [56, p. 56-57, 545]). Тем самым косвенно засвидетельствованно, что «проастий», как и прежде, относится к разряду пригородных поселков, а вокруг крепости концентрировались имения различных прослоек и групп господствующего класса, что содействовало обострению их противоборства за земли, расположенные под защитой оборонительных укреплений.

И главное - строительство крепостей в сельских местностях продолжалось. Сказанное подтверждают не только рассмотренные ссылки акта описания границ землевладений в округе Иериссо, составленного в 1103 г. Сгуром, на «новую крепость» [47, № 50.49-53, esp. № 50.50] в сочетании с упоминанием крепости Иериссо в практике Радоливо 1104 г. [47, № 52.571 etc.], но и весь ход дальнейшего развития византийского села. Может быть, с точки зрения проблемы «укрепления» села не самым типичным, но довольно выразительным примером могут служить сообщения ряда 


\section{ВИЗАНТИЙСКОЕ ОБЩЕСТВО И ГОСУДАРСТВО}

актов из архива Кутлумушского монастыря, прежде всего акта 1369 г. Иоанна Владислава, валашского воеводы, и завещаний Харитона, игумена названной афонской обители. Эти документы показывают, с какой тщательностью в середине - второй половине XIV в. разрабатывались планы и осуществлялись работы по фундаментальному укреплению монастыря. Их инициатором выступали высшие представители господствующего класса, а строили по сути «крепость», как называют составители

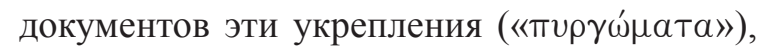
включая крепостные стены и «великий пирг», насельники монастыря [33, № 26.1-5 etc., 13-20, 53-57 etc.; № 29.15-16, 21-25, 52-59 etc.; № 30.34-38, 40-41, 44-51 etc., 107-117 etc., 124-126 etc.]. И хотя сказанное в данном случае касается в первую очередь самого афонского монастыря, без всякого сомнения следует утверждать, что подобные немалые заботы обращались и на удаленные периферийные поселения.

Сельские укрепления. Многочисленные свидетельства византийских актов засвидетельствовали также укрепления, которые бывали обозначены с помощью понятия «фрои́рıоv». Однако ж это понятие, будучи практически синонимом понятия «каструм», что подчеркнул в свое время Ж. Дагрон, имело весьма обширный смысл и значение ([73, p. 401]; также см.: [146, p. 186]). Современники эпохи Средневековья иногда использовали

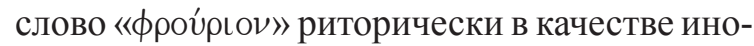
сказания, подразумевавшего аллегорическое значение «оплот» или «крепость». В некоторых случаях указанная коннотация ощутима и при обозначении реально существовавших укреплений, воздвигаемых для защиты монастырями непосредственно в их черте или рядом с обителью (напр., см.: [33, № 23.11-13 etc.; № 31.20-21; 31, № 4.25-29 etc.]; также см.: [32, Append. VI.6-7]). В частности, может

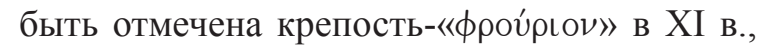
сооруженная при строительстве Ксенофонтского монастыря на Афоне [43, № 1.28-29 etc.]. Но особенно часты документальные

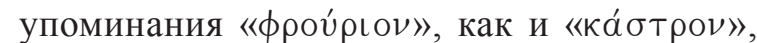
поздневизантийского времени, на которые нужно обратить внимание, даже если они относятся к укреплениям городских центров, как крупных, так и малых, и прилегающих к ним окрестностей (напр., см.: [42, № 126.10-11, 28; № $141.8 ; 38$, № 9.7; 36, № 123.25-26]). Безусловно, укрепления крупных городов обладали сложной инженерно-строительной структурой, на что указывает применительно к оборонительной системе Константинополя термин

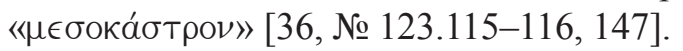

В то же время некоторые документы середины - второй половины XIV в., в том числе поземельные описи, удостоверяют расположение укреплений «фрои́рเоv» в сельской местности, в частности, в Скордихи [44, № 28.26-27; 36, № 159.34-35]. А судебное постановление Стефана Радина, кефалы Фессалоники, вынесенное в 1358 г., упоминает о проскафименах «в такого рода крепостях»

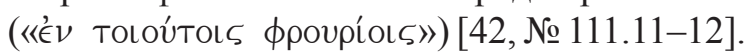
Особого внимания требуют к себе сведения документов, относящихся к истории хориона Комитисса (о хорионе Комитисса и воздвигнутых там укреплениях подробнее см.: [15, c. 221-256, особ. с. 227-228]), которые исходят от афонского прота Исаака. В первом из них, 1325 г., прот сообщает о том, что в названном хорионе, где располагался ивирский метох, была сооружена «крепость» («ка́бтроv») [48, № 82, esp. 11. 3-5, 8-9, 12-13, 13-16 etc., 26-27, 42-43, 48-49, 51-52 etc.]. В последующем акте, 1326 г., афонский прот Исаак для обозначения этого оборонительного сооружения в хорионе Комитисса, сообщая о планируемом поселении там людей «извне», использует как обозначение «ка́бтроу» [48, № 83, esp. 11. 25-26, 27-28], так и «фрои́рıоv», указав, что эта крепость населена эпиками [48, № 83.8 , $14-15,23-24,28-29,28]$. Построение этого сооружения отмечено и в других документах,

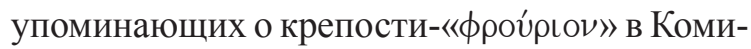
тисса [41, № 63.87-89, 106-108].

Среди прочих документов, касающихся крепостей-«фрои́рเоv», выделяется соглашение о возведении в Семалту, метохе Ватопедского монастыря, одним из монахов, - документ сохранил лишь его мирское имя Петр, - такой крепости, где обозначение «фрои́рเоv» представлено как первая часть градации различных видов укреплений, включая «пирг» и «кастел-

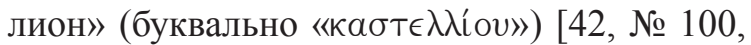
esp. 11.4 etc.], которое оказалось в поле зрения К. Смирлиса [135, p. 189-205, bes. S. 190 u. а.]. В данной градации прежде всего обращает на 
себя внимание рецепция латинского термина «castellium», известного в странах средневековой Западной Европы в качестве обозначения малых по своим размерам крепостей (о термине «кастеллион» и распространении данного вида укреплений подробнее см.: [150, p. 59 etc., 71-72]). Они, будучи проявлением общей закономерности развития аграрного социума в условиях дефрагментации власти и управления, способствовали локальной концентрации производительных сил поместного крестьянства и служили для защиты местных сельских общин. К слову сказать, приводимая концепция стала предметом широкого обсуждения еще в 80-х гг. прошлого столетия (подробнее см., напр.: [61, p. 170-171 etc.; 82, p. 177-189 etc.; 109, p. 197-204 etc., esp. p. 201-202]; также см.: [71, p. 75-76]; там же см. основную литературу). А упомянутая градация наглядно свидетельствует: Средневековая Византия следовала той же тенденции, о чем прямо заявляет П. Туберт [142, p. 382]. Тому не противоречат и изыскания, которые проделал названный К. Смирлис, выявив сопоставления «кастеллион» с «пиргами» $[135$, p. 193 etc.]. И хотя подобные сочетания в актах крайне редки, такие описания, скажем,

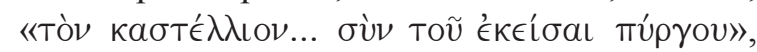

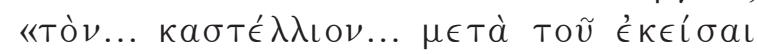

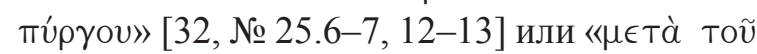

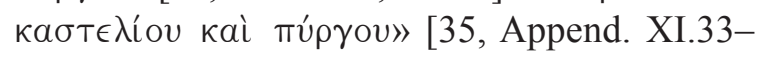
34], позволяют говорить о неоднозначности использованных в них обозначений укреплений (французские интерпретаторы для обозначение термина «кастеллион» прибегают к понятиям «châtelet», а также «fortin» и тому подобной терминологии, напр., см.: [32, p. 183; 47, p. 216; 42, p. 151, 245, 253]). Это отмечает и сам К. Смирлис, говоря о том, что речь идет о «башне с укрепленной окружностью» («a tower with a fortified circuit») [135, S. 193].

Автору этих строк остается непонятным, почему греческий исследователь упустил из виду подробное сообщение Прокопия Кесарийского, который в своем известном трактате «О строениях» описал реконструкцию городского укрепления. Тогда верхние ярусы его башен («пиргов») были защищены дополнительной куполообразной каменной кладкой,

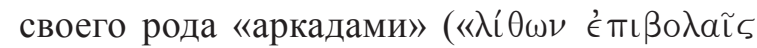

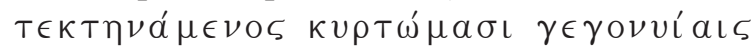

0ó $(\omega \nu »)$. Для обозначения вновь воссозданных укреплений историк Юстиниана использовал

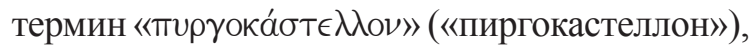
пояснив, что «кастеллами (“кабте́ $\lambda$ 入очऽ”) называются укрепления (“та̀ фроúpı а") на латинском языке» (Procopii Caesariensis De Aedificius Libri VI.II.5.6-9) [130, p. 62.16-25]. Объяснение содержания этого термина, безусловно, создает предлог к последующему осмыслению содержания средневековых византийских описаний. Они, помимо всего сказанного, ведут современного ученого к пониманию того, что во многих случаях, наверное, пирг воздвигался не изолированно, а предполагалось его соединение с примыкающими к нему иными оборонительными сооружениями, как показал Прокопий, посредством крепостных стен ([103, p. 32]; также см.: [128, p. XXIX]). На славянском языке, как известно, подобная «окружность» называлась «ограда», «оградъ», иначе «городъ» или «градъ»! Значения этих понятий не ограничивались экивоками на «забор» с греческими лексическими прототипами

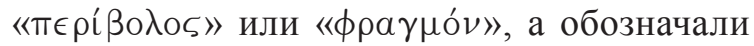
также «загороженное место», «город», «град»,

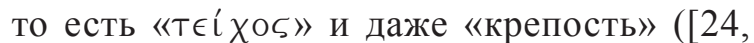
ст. 608-610]; ср.: [22, ст. 555-557, 575-576; 23 , ст. $1351-1352 ; 4$, с. $125 ; 11$, с. 122 и дал.]; также см.: [28, с. 13-14]).

Косвенно такое понимание изучаемого термина подтверждает описание тропы, которая «кружит внутри кастеллиона» (букв.

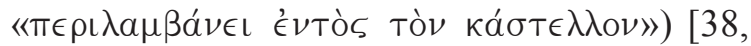
№ 20.36; № 21.19, 38; № 22.26; № 25.12-13]. Кроме того, нельзя не принять во внимание также еще один документ, так или иначе приписываемый Иоанну VII Палеологу, согласно которому предусматривается натуральное и денежное обложение «ради охраны кастеллия

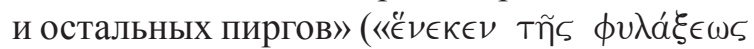

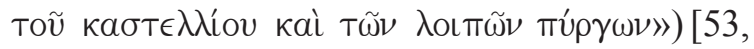
№ 45/6-II.13-14]. Исходя из сказанного оправданно толковать изолированные упоминания названного укрепления в документах XII$\mathrm{XV}$ вв., относящихся как к материковой части страны [47, № 52.184-185; 42, № 81.A.81; № 81.В.76; № 105.20-21; № 107.7-8], так и к Лемносу, где упоминается «заброшенный

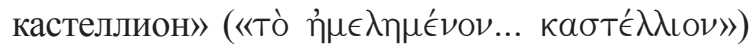
[35, № 126.12-13; № 136.62; № 139.60] и «пале-

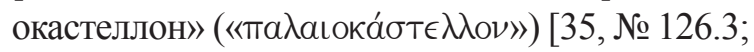




\section{ВИЗАНТИЙСКОЕ ОБЩЕСТВО И ГОСУДАРСТВО}

№ $127.7,12,18]$ и касающиеся их краткие реплики [35, Append. XVI.1-2]. Это понимание оправданно распространить и на инвари-

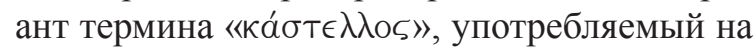
Лемносе [38, № 20.35-36; № 21.18-19, 37-38; № 22.25-26; № 25.12-13]. Реалистичность этих наблюдений над «кастеллион» отчасти удостоверяет византийская периферия, в частности, поземельные описания в венецианских владениях на Крите, где встречаются упоминания «castello», которые, надо подчеркнуть, не отождествляются непосредственно с региональными крепостными сооружениями ([153, № 1.1, б. 302, 304, 307]; о системе средневековых крепостных укреплений на Крите подробнее см.: [136, p. 101-114]). Показательно, что подобного рода укрепления, будучи построены в монастырских имениях, несмотря на их, вероятно, ветхое состояние, что можно предполагать при использовании обозначения «палеокастеллон», продолжали использоваться и в целях защиты, и для проживания зависимых работников ([35, № 127.5-8, 17-19 etc.]; также см.: [34, Append. II.66-67, 68-69; Append. XI.33-35; Append. XVI.1-2]). Что же касается собственно византийских пределов, то характерно завещание великого примикирия Иоанна 1384 г., сообщающего о построении военачальником на острове Тасос пирга и крепости-«фрои́рıоv», населенных местными жителями, что подтверждает своим актом патриарх Нил [38, № 10.16, 20-21, 45-46; № 11.5-7].

Установить разницу между названными видами укреплений довольно трудно, так же как и различия между укреплениями

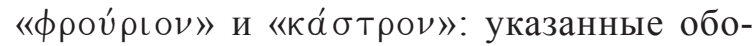
значения взаимозаменяемы по определению (напр., см.: [141, р. 282]). По всей видимости, приводимые понятия прилагались к различного типа оборонительным сооружениям без строгой терминологической точности, сами же защитные укрепления, в свою очередь, обладали какими-то отличиями, обусловленными замыслами их заказчиков и строителей, качественными особенностями строительства, складками местности, в которой они возводились, и тому подобными обстоятельствами. По совершенно справедливому замечанию одного из современных медиевистов, каждое общеизвестное из «обозначений места» («place-names») типа «castrum», «castellum» и других обретает свое содержание в качестве отсылки на город или деревню в зависимости от локальных условий использования данных понятий [76, p. 86 etc.]. Именно к такому пониманию проблемы фактически склонялись, надо признать, именитые соавторы и оппоненты Ж. Лефора, когда они в стремлении выявить различия между городами средневековой Южной Италии и Византии на рубеже 80-90-х гг. вернулись к ранее прошедшей дискуссии о сути византийских городов и укрепленных сел, известных под обозначениями «кастра» [116, p. 30-31 etc., 33-37]. И хотя выводы французских специалистов на этот счет не обрели отчетливых очертаний [116, p. 60-62; 115 , p. 83-88 etc.], продолжение обсуждения вопроса о «кастра» и тому подобных обозначений укрепленных городских центров выводят ученых к вполне ясно сформулированным методологически принципиальным положениям о функциях и исторической роли средневекового города в его сравнении с селом [116, p. 37-41 etc., 46 etc.]. Но даже хрестоматийные методологические выкладки, в свою очередь, не позволяют ответить на вопрос о том, какое из названных видов византийских укреплений в наибольшей степени соответствовало западноевропейским «замкам», укрепленным строениям, которые совмещали в себе оборонительные функции и служили для проживания (подробнее см.: [10, с. 68-72]). Надо сказать, что в последние десятилетия византинисты достаточно часто прибегают к названному «западноевропейскому», если так уместно говорить, термину, обозначая, как правило, без каких-либо пояснений, крепостные сооружения как «замки» (напр., см.: [89]; также см.: [80, p. $116 ; 63$, p. 504, 506, n. 72, 507-509, 513, n. 174; 79, p. 604; 78, p. 617; 133, p. 624-627; 96, р. 639-640]). К слову сказать, так сделал еще Г. А. Острогорский [15, с. 227]. Однако современному специалисту надлежит понимать, что за подобной метонимией стоит вся многостолетняя история влияния византийской фортификационной архитектуры на западноевропейские замки, которое приняло особенно наглядный вид в эпоху крестоносцев (подробнее см., напр.: [76, p. 62 etc.; 51, p. 21, 27-28; 103, p. 25-34]; также см.: [128, p. XXIII etc., esp. p. XXVIII etc.]). С точки зрения же 
решения проблемы укрепленного средневекового византийского селения, необходимо помнить о том, что именно на территории таких «замков», за стенами прочих крепостей, будь-то «фрои́рเоv», или «кастра», окрестные поздневизантийские селяне искали приюта во времена участившихся военных угроз и вражеских нападений [63, p. 508].

Вероятно, некая подобная ситуация, возникшая «из-за нападения врагов», дала толчок конфликту Ватопедского монастыря с «импе-

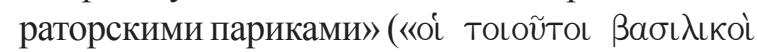
та́роцкоเ») из хориона Св. Мамы, как указывают издатели уже упоминавшегося судебного постановления 1358 г. Стефана Радина. Названный фессалоникский кефала урегулировал спор крестьян, причиной которого стала стоимость компенсации, как допустимо, предположительно, понимать, за снос их домов и строительные материалы, которые, возможно, были даже использованы для сооружения на подступах к указанному селу укреплений, а именно

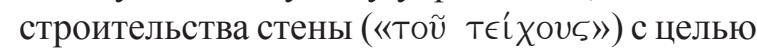
организации на выбранном монахами для того

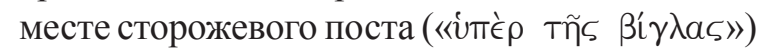
(подробнее см.: [42, № 111.1-26, esp. 11. 5 etc., 16-20]; о значении термина «вигла» см.: [140, p. 2167]). В результате крестьяне, более 60-ти дворохозяйств, получили свою компенсацию [42, № 112], что косвенно говорит о весьма значительном размахе произведенных тогда строительных работ по сооружению фактически новой крепости. В любом случае приводимые данные о крепостных укреплениях в Поздней Византии не оставляют сомнений в том, что расположенные на незначительном удалении друг от друга мелкие крепости, испытавшие натурализацию экономики, и несмотря на это

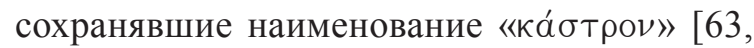
p. 501], и близлежащие села образовывали единую долговременную систему.

Пирг. Столь же несомненно, что в Поздней Византии уже не были единичны сельские селения, огражденные стенами и защищаемые иными оборонительными сооружениями. Непрерывные набеги неприятеля - участников феодальных усобиц, нападения пиратов, рейды турок и тому подобное - вызывали настоятельную потребность в защите мирного населения сельских местностей. И как уже показано, там повсеместно возводятся уже упоминавшиеся «пирги» или так называемые жилые башни - оборонительные постройки, служившие убежищем селянам во дни военных испытаний [101, p. 226]. Собственно говоря, «пирг» (пи́руоธ) [140, p. 1760-1761], как своего рода системный компонент фортификаций населенных пунктов, прежде всего, конечно, городских центров, альтернативный

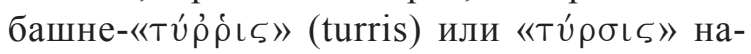
ряду с крепостными стенами, известен издревле [114, p. 907-909, esp. p. 907]. Со всей определенностью можно говорить о том, что башни, как и прочие виды укреплений малых форм, - общеевропейское явление, получившее яркое развитие в различных странах эпохи Средневековья [127, p. 7-9]. Это касается и Византии, что подтверждают, помимо всех прочих, свидетельства раннесредневекового византийского законодательства (напр., см.: CJ.I.04.026.Pr. [69]; CJ.VIII.11(12).018.Pr. [69]; NJ.103.Praef.Pr. [70]; B.A.LVIII.12.018 [59]; PT.LVIII.12.018 [158]; SBM.Kappa.035 [137]). Согласно мнению М. Уиттоу, в X-XI вв. пирги, сельские фортификации, которые ученый уподобляет средневековым замкам, были крайне редки, и они, по убеждению специалиста, не образовывали единой «сети» [150, p. 61-62]. В свою очередь, Ж. Лефор, раскрывая оборонные функции пиргов, относит их к особому виду укреплений, число которых заметно возрастает в период XII-XIV вв., в особенности во вторую половину XIV столетия [105, p. 100 etc., 102-103]. В настоящее время системное исследование пиргов проделал, как уже было представлено, К. Смирлис. Ученый выявил не только конструктивные особенности известных афонских пиргов, но и систематизировал данные о них [135, S. 189-205, bes. S. 190-194, 197-203]. Поэтому нет необходимости долго рассуждать об описаниях пиргов в фальсификатах раннесредневековых византийских документов, что само по себе лишь оттеняет значение подобного вида оборонительных сооружений в последующую эпоху, простиравшуюся вплоть до Поздней Византии, поскольку одна из подложных грамот соотносится со временем правления Андроника II Палеолога и указывает на местоположение пиргов в окрестностях Иериссо и в других сельских и городских местностях [44, Append. a).13-14; ß).20-21; $\gamma) .13-14,19-20,41]$. 


\section{ВИЗАНТИЙСКОЕ ОБЩЕСТВО И ГОСУДАРСТВО}

По свидетельству современных знатоков региональных достопримечательностей Греции, история сельских селений и сохранившихся там строений восходит к Средневековью. В частности, туристам предлагается посетить такие села на Южном Родосе [12, c. 187]. Конечно, множество древних по происхождению селений известно и в материковой Греции. Но даже там на самом деле, помимо храмов, лишь пирги, пожалуй, единственные гражданские сооружения села, сохраненные временем от рассматриваемой эпохи $[9$, с. 136 , 138; 62, p. 652-653; 118, S. 80; 55, p. 314]. Руины пирга можно найти на раскопе почти любого средневекового села [101, p. 181]. В середине XIII в. отмечен покосившийся изза большого безвременья остов сложенного из камня глинобитного «маленького пирга»

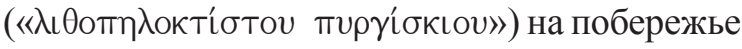
Афонского полуострова, который принадлежал заброшенной к тому времени святогорской обители [33, № 2.25]. В подобных случаях нередко ветшали и сами пирги, о чем говорят, к примеру, упоминания в поздневизантийских актах и поземельных описях сельского «раз-

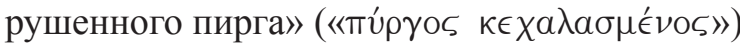
[30, № 9.48] или просто сельского «старо-

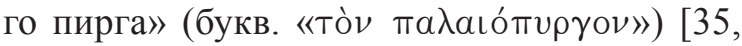
№ 108.739].

Разумеется, из-за угрозы вражеских нападений пирги в сельских селениях сооружались и в предшествующие столетия византийской истории, в особенности, если указанное обозначение дополняет атрибутив «старый», предполагающий сохранение останков не просто старого, а заброшенного укрепления (напр., см.: [46, № 4.49, 54-55; № 29.11]; также см.: [47, № 39.19; № 52.434-435]). В то же время возводились и новые башни. Достаточно указать на образное свидетельство «Типика» Григория Пакуриана. Здесь рассказывается о необходимости сооружения пирга на холме вблизи странноприимного дома ( $\xi \in \nu \circ \delta о \chi \in i ́ l o v)$ названного монастыря. По всей видимости, имеется в виду монастырская богадельня в хорионе Стенимаху, описание которой приведено в предшествующих разделах типика. Тут же однозначно объясняется предназначение намеченного к постройке пирга: «...если случится здесь некий страх, в пирге сторожить, когда бы пришел некто из чинящих насилие

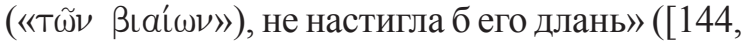
p. 230.1-3]; см.: [144, p. 228.5-22 etc.]; также см.: [26, с. 200-201]). В поздневизантийский период пирги возводили как дополнительные к крепостям оборонительные сооружения. В частности, при создании оборонительного рубежа на полуострове Кассандра в начале $\mathrm{XV}$ в. один из пиргов был восстановлен вместе с крепостной стеной на старом фундаменте к тому времени разрушенного укрепления [44, № 28.12-14].

В этой связи уместно напомнить о том, что последнюю осаду Константинополя, завершившуюся в мае 1453 г. его окончательным падением, турки начали со взятия отчасти штурмом, отчасти измором размещавшихся в столичной «хоре» пиргов, где искали спасения занятые своими «делами» «деревенские мужики» ([102, p. 149.8-11]. Об оборонительной системе средневекового Босфора и сооруженных там «башнях» подробнее см.: [54, p. 91-100]). По всей видимости, описанная ситуация сама по себе отнюдь не являлась из ряда вон выходящей. По крайней мере, некоторые сведения о пиргах, допустим, Дохиарского монастыря, позволяют предполагать о размещении там именно крестьян, как это подтверждается сообщением о «крепостице» Равеникии с расположенным там пиргом, париками и «элевтерами» [32, № 25.5-7 etc.]. Равным образом в 1338 г. Ксенофонтов монастырь населил зависимыми крестьянами один такой пирг в Псалидофурна [43, № 25.96 etc.]. Эти сведения подтверждаются хрисовулом 1352 г. Стефана Душана, согласно которому в монастырском пирге нашлось место для чужих (ксенопа-

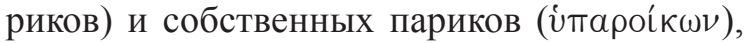
а также так называемых проскафименов [43, № 29.11-12].

Подчас подобные укрепления в некоторых документах, в частности, типике Менекейского монастыря Иоанна Продрома в Серрах, получают обозначение «кула», заимствованное из турецкого языка: «коu入ás» ([111, Append. I.22, p. 176.32-35]; также см. вкладную запись XIV в.: [111, Append. VIII, p. 193]). Как это укрепление характеризует Р. Фолк применительно к актам названного монастыря - «Art Bastion» [149, S. 254, Anm. 983]. По всей видимости, приведенное турецкое обозначение получило заметное распро- 
странение на Балканах поздневизантийского времени, что подметил Г. А. Острогорский [15, с. 227]. Прямым потверждением тому служит «Законник» Стефана Душана, где в статье о «градозидании» упоминание «кулы» сочеталось с обозначением «град» (ст. 127) ([5, c. 196]; там же см. комментарий; также см.: $[25$, c. $54-55,126-127])$. Кула приравнивается и западноевропейскому «донжону», и греческому «пиргу», и прочим укреплениям подобного типа ([20, с. 340-342]; также см.: [19, с. 164; 7, c. $513 ; 16$, с. $62-63])$. Однако турецкое по происхождению заимствование даже в последний период существования Византии не могло вытеснить греческого термина, что наглядно подтверждают документы названного монастыря, включая его типик. Там встречается используемое для обозначения укрепления, где монастырский игумен собирался возвести церковь, также понятие «пирг» [111, Append. I.22, p. 176.41-43, 47-48]. Точнее говоря, в документах Менекейского монастыря первой четверти XIV в. сообщается о «великой баш-

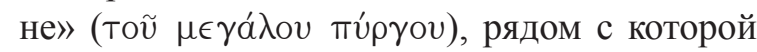
на близ протекавшей реке была сооружена мельница. Это позволяет предполагать, что «великий пирг» Серр, который А. Гийу, издатель актов, идентифицирует как «крепость», стал средоточием хозяйственной жизни в окрестностях города [111, № 9.22; № 10.24]. В свою очередь, акт 1339-1342 гг. упоминает «пирг» св. Николая с рядом расположенным садом. В то же время локализация этого пирга свидетельствует, что он неразрывно связан с «крепостью» Серр, составляя неотъемлемую его часть как один из компонентов обширного городского социально-экономического комплекса [111, № 35.7-19 etc., esp. 11. 12-13]. Одновременно в том же акте имеется ссылка на еще один «пирг», по всей видимости, в одном из пригородных метохов Менекейского монастыря, который был сложен, как уточняется, из

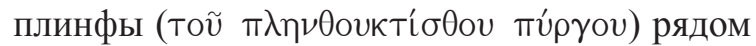
с жилыми домами и другими хозяйственными объектами [111, № 35.54-61 etc.]. Здесь можно сразу же повторить, что нередко пирги возводились в ближайшей округе городов, как это подтверждает практик 1338 г. Константина Макрина, зафиксировавшего пирг, который, по всей вероятности, служил для защиты мельницы в метохе Ватопедского монастыря под Христуполем [42, № 82.9-10, 13-14, 60]. В указанной связи обращает на себя особое внимание дар монаха Арсения Цамплакона Ватопедскому монастырю, сделанный в 1356 г., когда этот представитель достаточно знатного рода завещает афонской обители наследственные имущества, в том числе родовое имение

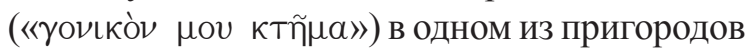
Фессалоники [42, № 107]. Притом завещатель сообщает о том, что им и его родными высокопоставленными братьями там на паях был отстроен пирг, половина которого, как и всего имения, в дальнейшем принадлежала Арсению [42, № 107.11-24, esp. 11. 21 etc.].

В конечном счете само слово «пирг» в последние столетия существования Византии становится синонимом обозначения сельских и пригородных «имений», возникающих там поселений или поселков и используется в качестве их собственных названий. При этом было бы недостаточно указать на пирг Лавры Афанасия в Иериссо, который с конца XIII в. поставлен в один ряд с другими землевладениями и хорионами монастыря «вместе со его правами» ([35, 89.101-102; 36, № 118.94-95]; также см.: [30, № 9.46-48 etc.]). Показательны сведения документов рубежа XIII-XIV вв., в которых упоминается «эконом пирга». Иначе говоря, идет речь о своего рода хозяйственных усадьбах, находящихся под эгидой монастырских управляющих, которые занимались скупкой земли. В одной из таких усадеб хозяйственную активность проявил «эконом пирга»

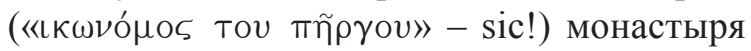
(метоха) Ксеропотаму (напр., см.: [41, № 42.1, 3-4]). Другая усадьба, принадлежавшая Лавре Афанасия, выступала под названием «Пирг». В этом имении, ставшим местом средоточия экономической деятельности названного монастыря, приобретавшего близлежащие земельные участки, как выясняется из купчей, отмечена причастность к тому «эконома Пирга» («íкоро́ [35, № 87.7-10; № 88.7-9]). Наряду с тем в поземельной описи Лавры Афанасия 1321 г. выделяется отдельно землевладение «Пирг» [35, № 108.697-714], а также известен земельный клин («тнп̃ $\mu \alpha »)$ в местности «Пирг», описанный в 1324 г. апографевсом Георгием Фарисеем в Ермилее [35, № 114.5-32]. И типик монастыря Богородицы «Твердой Надежды 


\section{ВИЗАНТИЙСКОЕ ОБЩЕСТВО И ГОСУДАРСТВО}

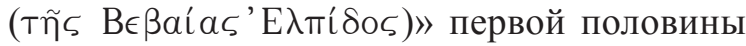
XIV в. в ряду владений, полученных монахинями от основателей и вкладчиков этого монастыря (подробнее см.: [149, S. 255-265]), называет половину «имения» (ктп̃нато ), которое идентифицируется, будучи «прозван-

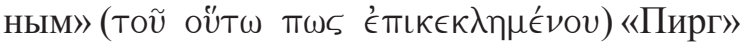

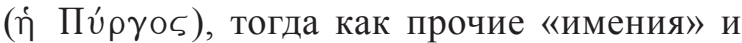
имущества атрибутированы по их расположению на территориях окрестных хорионов [42, № 79.15-16].

В то же время один из актов Ватопедского монастыря, не идентифицируя по названию некий пирг на полуострове Кассандра, позволяет утверждать, что это укрепление находилось на границах землевладений афонских монастырей [42, № 79.15-16]. Но само по себе отмеченное обстоятельство вовсе не означает того, что примыкающая к «жилой башне» территория, как бы ее не обозначали, будь то «периохи», «топотесия» «пирга» или иным образом, согласно документальным свидетельствам, при хозяйственном ее использовании не уподоблена некоим имениям или усадьбам, где налаживается сельскохозяйственное производство, например, возделываются виноградники (напр., см.: [42, № 84.1-2 etc., 9 etc.]). Сообразно тому, скажем, в хрисовулах 1346 и 1348 гг. Стефана Душана сопоставлено в одном ряду «все принадлежавшее» Ватопедскому монастырю, а именно в том или другом варианте «имения» («Кти́ $а \alpha а »)$, «метохи» и «пирги», равно как вслед за ними описаны и расположенные там «хорионы» [42, № 93.11 etc.; № 97.6 etc.]. При этом сербский правитель добавляет к их общему перечню и построенный названным монастырем пирг в хорионе метоха Св. Георгия, очевидно, с целью подтвердить права монастыря на село, которое ранее принадлежало стратиотам Варваринам ([42, № 97.8-9]; также см.: [42, Append. VI.7-11 etc.]; о Варваринах подробнее см: [123, p. 360363]). В свой черед, в акте 1409 г. приводятся указания на пирги, воздвигнутые на принадлежавших Дохиарскому монастырю территориях сел Халкидики, а именно Перигардикейа, Ермилия и Калокампу (Диаболокампу). Там обозначение «пирг» по существу замещают термин «хорион», который прилагался к селу Мариана (Амариана) [32, № 53.2-5]. И соответственно перечни поселенных в «жилых башнях» монастырских крестьян вместе с членами их семейств и подсчетами уплачиваемых налогов и податей фактически ставят пирги в один ряд с собственно господскими имениями и хорионами, куда власти разрешали дохиарским монахам привлекать новых поселенцев из соседних областей [32, № 53.5 etc., 31-33].

Не потому ли иногда «меж афонских монастырей», как показывает акт прота Иоанна 1288 г., возникали целые «баталии» за право обладать пиргом и обустраивать рядом с ним свои подсобные хозяйства? [30, № 11.10-17 etc.] Так, в конце первой четверти XIV в. монахи Ксенофонтова монастыря, стремясь получить равноценное возмещение за утраченный ими ранее свой метох, выдвинули соответствующие требования афонскому проту Исааку со ссылкой на акт 1089 года. Здесь стоявший тогда во главе Святой горы прот Павел отметил, в частности, изъятие у ксенофонтцев их метоха вместе с пиргом, который некогда построил там настоятель и прот Герасим в соответствии с постановлением василевса Никифора III Вотаниата ([43, № 18.11-16]; ср.: [43, № 1.136-141]). Как и в те далекие времена, в поздней Византии пирги строили по решению будь то центральных или местных властей и крупных земельных собственников, в особенности монастырей [99, p. 162-163]. Именно они в первую очередь бывали озабочены защитой своих владений и хорошо налаженных хозяйств. В этой связи, наверное, нет нужды описывать подробно возведение во второй половине XIV в. «большого пирга» Кутлумушского монастыря на средства правителей Угровлахии [33, № 29.16-18 etc.; № 30.35-38 etc.]. Ведь они наряду с «жилой башней» по политическим соображениям поддержали и построение целой крепости [33, № 26.3-5, 15-16, 53-57; № 29.15-16 etc., 21-22, 22-25, 55-56, 59-60; № 30.39-41 etc., 44-50 etc., 112-116 etc., 125-126].

Если же рассказывать не о столь масштабных сооружениях, то оправданно указать на строительство пирга в монастырском метохе, расположенном в хорионе Св. Маманта на Халкидике [126, p. 156], который был возведен, по всей видимости, в первые десятилетия XIV в.

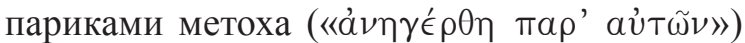
[41, № 68.43-45]. Впоследствии этот факт не только был подтвержден в 1338 г. сведе- 
ниями практика Константина Макрина, но и дополнен данными о построении «сызнова»

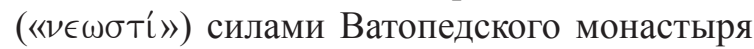
еще одного пирга в метохе Св. Димитрия [126, p. 155-156], который был заселен проскафименами, тогда как поселенные к тому времени в хорионе Св. Маманта названы париками [42, № 81.A.7-9 etc., 53-65 etc.; № 68.B.43-45 etc.]. Здесь, неподалеку от пирга Св. Маманта, как выясняется позже, находились земельные владения и светских представителей господствующего класса, которые со временем перешли Ватопедскому монастырю [42, № 130.6-9 etc.]. С точки зрения принципов обустройства внимание заслуживает пирг Ксенофонтского монастыря, воздвигнутый его насельниками «на большой укорененной ( скале» [45, № 24.21-22]. Несомненно, даже если документы не говорят об этом прямо, афонские отшельники стремились разбить свой виноградник и построить скит «вблизи», то есть под прикрытием пирга ([31, № 7.3-5]; также см.: [33, № 15.93]).

Без сомнения, сооружение даже самых простых по своим конструктивным особенностям «жилых башен» являлось довольно сложной технической и весьма дорогостоящей задачей, вероятно, почти всегда требовавшей привлечения профессиональных строителей. Это следует из предъявленного в середине XIV в. заказчику, по всей видимости, Ватопедскому монастырю, счета со стороны уже упоминавшегося в связи с возведением крепости-«фрои́рıоџ» в Семалту монаха Петра, за расходы по сооружению там пирга. Основу расходов составляли выплаты остающимся неназванными в платежном документе строителям - «мастерам» и «протомастеру»

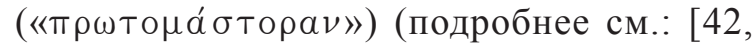
№ 99.1-3 etc.]; ср.: [42, № 100]). Независимо от того, подразумевается ли в указанном документе под «пиргом» действительно «жилая

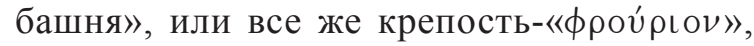
удорожанию строительства в данном случае способствовала необходимость обращения мастеров-строителей в железоделательные мастерские, где изготавливались металлические ворота и гвозди в количестве 900 шт. «больших» и 700 шт. «сферических» [42, № 99.4-6]. Потребность в них вызывало, судя по всему, сооружение деревянных конструкций, на- верное, внутреннего интерьера и чердачных помещений, что в их совокупности, очевидно, нельзя считать неквалифицированной работой.

Тем не менее, зачастую возникавшие угрозы пробуждали инициативу местных монастырей в их имениях возводить или обновлять пирги на собственные средства - «ради сторожи и крепости», как говорят документы Дохиарского архива ([32, № 21.20-21 etc.; № 43.7-10; № 44.7-8]; также см.: [33, № 9.2326, 28-29, 30-36; 43, № 27.10-11 etc.]). С той же целью, скажем, монахи монастыря Дионисия в начале XV в., задумав возобновить на полуострове Кассандра палеохорион Мариский, планировали начать с возведения там пирга, который, будучи построен по побуждению василевса за счет собственных расходов, служил бы для защиты и поселения там земледельцев [31, № 13.3-6, 10-16; № 17.3-5, 6-8 etc.]. Строительство этого пирга, по всей видимости, было сопряжено или, по крайней мере, совпадало по времени с восстановлением в указанный период, что уже отмечено, укреплений на полуострове Кассандра. Во всяком случае возведенная там крепость упоминается в акте 1421 г., касающемся землевладений названного села [31, № 20.13-14, 19, 29, 34-37]. Порою сооружения такого рода устраивали на морском побережье, откуда его жителям нередко угрожали нападения пиратов. Готовясь к отражению врага, возведенные пирги использовали, как сообщает в 1362 г. дарственная Михаила Иераки, в качестве складских помещений, по всей видимости, для хранения товаров или запасов продовольствия [33, № 24.14]. В частности, заключенное в 1422 г. соглашение между монахами Алипийского и афонского Пантелеймонова монастыря о совместном использовании гавани и причала для монастырских судов, предусматривает хранение товаров на складе и остановку в жилых постройках под прикрытием близ возведенного пирга, который служил защитой торгового подворья от возможного нападения турецкого флота [40, № 19.8-15].

В то время жилые башни стремились размещать вдоль важнейших путей сообщения ([55, p. 317, 318]; также см.: [122, p. 133]). Благодаря этому пирги становились «ключевыми точками» практически всех описаний территорий крупных землевладений и сель- 
ских населенных пунктов с ведущими к ним дорогами и расположенными там хозяйствами (напр., см.: [29, p. 148; 41, № 14.51-53; № 14. Delimit.20-23; 42, № 81.A.23-24, 37-38; № 81.B.10-11; № 97.8-9; 3, № 18.26-28; 48, № 62.5-6, 7-8; № 70.204-205, 256; № 75.323$324,386-387$; № 79.304-305, 375-376; 49, № 86.210-211; 45, № 14.217-218; 32, № 27.4-5; № 28.20-21; 43, № 12.26; № 13.89-90; № 25.15, 24, 31-32; Append. I.9; Append. II.46]). Скажем, в хорионе Иериссо, где, вероятно, за столетия был построен далеко не один такой пирг, в начале XIV в. выделялась «жилая башня» Лавры Афанасия (см.: [45, № 10.24]), позднее - пирг, который размещался в метохе Ивирского монастыря [49, № 88.17-18]. К числу важнейших поместных укреплений, наверное, следует отнести и пирг в переданном во владение Мануилу Тарханиоту и его сыну Иоанну хорионе Лоротон [36, № 149.2, 10-11, 18]. А строительство «жилых башен» во владениях Ватопедского монастыря, как это было показано, к середине XIV в. сделало большую часть его многочисленных метохов, где отмечены семь пиргов, своего рода узловыми элементами системы оборонительных укреплений (см.: [42, № 108.13-17, 18-21]). Обладание ими для Ватопедского монастыря, безусловно, было настолько значимо, что монахи названной обители воспользовались подложным хрисовулом Иоанна V Палеолога для того, чтобы закрепить свои права на метох Просфорион вместе с выстроенным ими здесь пиргом (см.: [42, Append. IV.3-7 etc., 21-23 etc.]).

В то же время, как и на материковой части страны, нарастают практически сопоставимые тенденции на островных территориях Византии. Так, видимо, развивались сельские селения на Лемносе, где еще в середине XIV в. Ватопедский монастырь сооружает на собственные средства пирг в селе Мудру, как сказано в акте 1359 г. великого стратопедарха Георгия Астра, «во крепость

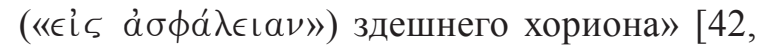
№ 114.17 etc., 25]. Получив поддержку со стороны власти, монастырь был объявлен полным собственником названного хориона, а строительство пирга там компенсирует предоставление налоговых изъятий и права селить здесь местных островитян и проскафименов [42, № 114.34-43 etc.]. Спустя несколько лет, в 1366 г., принятые решения подтверждает своим актом преемник названного выше сановника, Михаил Астра Синадин. Он сразу же отмечает сопряженность построенного ранее на Лемносе пирга Ватопедского монастыря с прочими «топосами и крепостями» на острове. А далее, опираясь на ранее жалованные простагмы и другие документы, Михаил Астра подкрепляет право монастыря на земельные владения на Лемносе, включая земельный клин, примыкающий к пиргу в хорионе Мудру, а также поименно указанных в грамотах париков [42, № 125.4-9 etc.]. Сообразно тому через два года составитель практика Ватопедского монастыря, касающегося его владений на Лемносе, отмечает уже отстроенный пирг монастырского метоха Мудру. Прежде всего внимание обращено на проживавших здесь, в построенных рядом с пиргом домах, проскафименов: они перечислены подворно, и предусматривается возможность привлечения монастырем новых крестьян различных категорий [42, № 128.4-5 etc., 44-46 etc.].

Равным образом на Лемносе в конце XIV в. монастырь Пантократора возводит пирг, куда по решению властей надлежало селить как «собственных людей» обители, так и чужаков-«ксенов» и «неизвестных казне»«анепигностов». Как следует думать, укрепление, получившее название Ано Хорион, размещалось на побережье в окрестностях села Еписперагос (Песпирагос) [38, № 20.5-9, 32-33, 51; № 21.2-3 etc., 12-13, 17, 31-32, 36 ; № 22.19-21, 24]. Согласно составленной позднее копии поземельной описи рубежа XIV-XV вв., пирг Ано Хорион фактически превращается в небольшой поселок [38, Pant. Append. Passim.]. Этот пирг был известен, по крайней мере, вплоть до последних десятилетий существования византийской власти [38, № 25.6-7 etc., 10]. Аналогичная ситуация, по всей видимости, прослеживается в хорионе Контовраки во второй четверти XV в., где

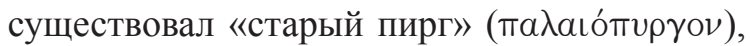
куда его владелец, Ивирский монастырь, получил разрешение заселить париков, перевезенных из континентальной Греции [ 49 , № 99.5-10, 12 etc.].

В свою очередь, составленное в последней четверти XIV в. завещание великого примикирия Иоанна и относящиеся к тому 
свидетельства других документов, касающихся пирга, построенного названным военачальником в прибрежной зоне («тері $\lambda \epsilon \gamma o ́ \mu \epsilon \nu о \nu$

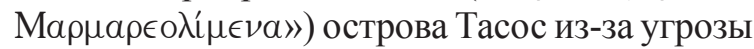
повторявшихся турецких нападений, показывают, что этот пирг стал дополнительным укреплением наряду со стоящей там же крепостью, буквально, выражаясь языком воинского командира, «то̀ фрои́рıоv». Она предназначалась защищать воздвигнутый поблизости храм, прочие жилые и хозяйственные строения и окрестные селения, связанные между собой локальной дорожной сетью, которая превращала описанные «фортификации» в единую оборонительную систему [38, № 10.16, 20 etc., 33, 34, 45-46; № 16.20 etc.; № 17.45-46].

Одновременно в поздневизантийской деревне происходит воссоздание прежних, разрушенных врагами, или даже закладка новых более сложных фортификационных сооружений [40, № 13.1-8]. Скажем, известно, что с предшествующего времени доселе хорион Гомату был окружен крепостными стенами, в черте которых находились дома части жителей [156, б. 223]. Помимо этого факта вызывает интерес предыстория строительства крепости в хорионе Комитиссы (подробнее см.: [55, р. 316-317]). В конце первой четверти XIV в. афонские монахи просили выделить им земельный участок на территории названного села, чтобы заложить крепость для охраны окрестностей. Подходящее место было выбрано неподалеку от монастырского метоха на неудобьях - каменистых, остававшихся по сю пору непаханными землях - в стороне от хорафиев и виноградников париков Ивирского монастыря, проживавших в том селении. В конечном счете прошение монахов было удовлетворено сполна и им отвели два надела. Один из них предназначался для строительства крепости, где резервировалось место для усадьбы Ивирского монастыря и его крестьян, а на другом - был размещен поселок с обслуживающим оборонительное сооружение людом [48, № 82.1-13, 42-53; № 83.1-10, 14-18, 23-29]. С указанного времени крепостные стены могли защищать даже относительно небольшие селения, а наличие в них укреплений, как говорилось, уже не всегда вызывало специальное внимание. Допустим, Иоанн V Палеолог, утвердивший в хрисовуле
1353 г. передачу хорионов Анциста и Веникия Пантелеймонову монастырю, умолчал о воздвигнутых здесь оборонительных строениях, тогда как через двадцать два года наследник прежнего владетеля этих сел, признав свершившийся факт, характеризует второй из названных населенных пунктов как «старую крепость» (та入ацока́бтроv) ([40, № 15.4-5]; cp.: [40, № 11.11-14]).

В результате в сельских местностях развертывается система укреплений в качестве оборонительного рубежа целого региона, в которой сельское поселение могло занимать соподчиненное, но, вместе с тем, иногда немаловажное положение. В связи с этим уместно вспомнить эпизод из «Истории» Иоанна Кантакузина, где описан рейд турок 1343 г. в районе Фессалоник. Тогда ими были уничтожены два села-«комы», обнесенные крепостными стенами и с сооруженными там пиргами [92, р. 392.19-20]. Ту же самую картину рисует «Хроника»» Псевдо-Франдзи применительно к Пелопоннесу накануне его падения под ударами турок. Столицу полуострова окружали пирги, возведенные как в близлежащих «комах», так и непосредственно в сельской местности, о чем хронист сообщает, прибегая к буквальному выражению «в полях»

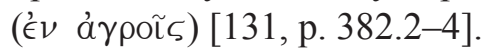

Именно значимость пиргов в качестве оборонительных укреплений была, по всей видимости, хорошо ясна для современников их сооружения, и потому, как в отношении крепостей, обозначения «Пирг» или «Старый

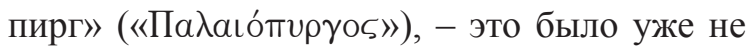
один раз отмечено, - с давних пор быстро превращались в названия прилегающих местностей и селений, где еще сохранялись, наверное, остовы прежних укреплений. В таких случаях фактически речь идет о местности окрест Иериссо ([41, № 14.37-38 etc.; № 14.Delim.3-6 etc.; 44, № 18D.I.7-8]; также см.: [41, № 34.5-6; № 37.2-4; № 43.2, 10-11, $25-26,36])$ или каком-то еще поселке (напр., см.: [41, № 14.52-53; № 14.Delim.22-23; 44, № 16.138]), или его части, скажем, «периохи Филантропу, что нарицаем Палеопиргу

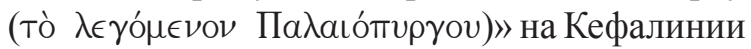
[160, 11. 182-183]. Равным образом следует вспомнить и о «топотесии Пирга» в предместье Фессалоники Калокаиридов, как его 
обозначил составитель документа 1341 г., тогда как за пару лет до этого в аналогичном акте речь шла всего лишь о «периохи» и «топотесии» заурядно обозначенного пирга (напр., см.: [41, № 87.1, 4-5]; ср.: [42, № 84.1-2, 9]). Сообразно тому, на полуострове Кассандра топоним «Пирг» естественным образом возник, вероятно, не без оглядки на древние укрепления, что зафиксировал акт, содержание которого возводится ко временам эпопта и анаграфевса Фессалоник, императорского протоспафария Фомы (Х в.) [34, Appen. V.8-9]. Впоследствии, логично предположить, так же

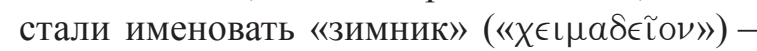
временное убежище пастухов [45, № 22.14 15]. А во владениях Вазелонского монастыря в Трапезунде название, весьма похожее на обозначение пирга, получил хорафий, то есть

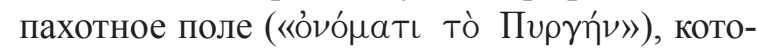
рое было расположено, по всей видимости, на каком-то участке местности ([27, № 104.35]; cp. [27, № 16.7]).

Здесь проявляется принцип преемственности, своего рода ретроспективы человеческого сознания. Он действует не только в отношении топонимов, воспроизводящих обозначение пиргов, но и связанных с ними укреплений «кастеллион». Достаточно сослаться на аллюзию указанного укрепления, которая возникает в изысканно утонченной риторической фигуре речи афонского прота Иоанна, воплощенной в акте 1169 г., посвященном восстановлению одного из монастырей:

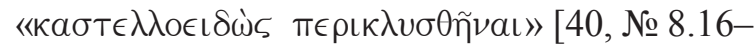
17 etc.]. Самое же обозначение «кастеллион» в том или ином виде становится названием местностей и размещающихся там местечек

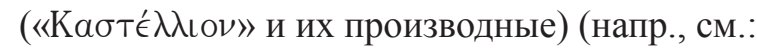
[41, № 15.229-230, 232]). Так, на Имбросе схожим образом назван монастырский метох («К $a \sigma \tau \epsilon \lambda \iota \nu о ́ \nu »)$, который находился рядом с местной крепостью [36, № 138.6-7 etc.]. Благодаря раннесредневековой традиции придерживающийся ее составитель одного из документов с описанием лаврского метоха Гомату на Лемносе отмечает вкупе выразительные сами по себе топонимы, подразумевающие существование на острове оборонительных укреплений «Кастелион» и «Пирг»

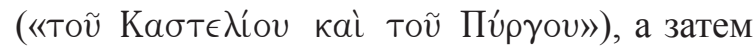
еще и «Кастри» («Кабтр́́») [34, Appen. II.66-67 etc., 70]. Более того, если название «Пирг», согласно тому же документу, могли присвоить монашеской келье в Карее, в Протате (см.: [34, Appen. II.77-78]), то сразу же нужно отметить, что ранее здесь действительно был сооружен

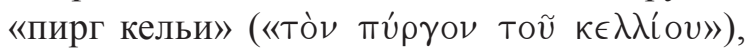
который вскоре объявлен афонскими монахами неколебимым оплотом «не только» Протата, а даже «всей Святой Горы», «фрурион»

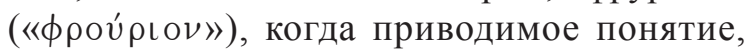
по всей вероятности, обретало переносное значение и символический смысл наравне с использованным тут же понятием «крепость»

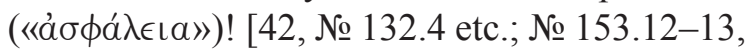
19-21 etc.]

И нельзя умолчать о том, что указанная топонимика была воспринята славянами, как доказывает средневековый перевод хрисовула Андроника II Палеолога 1308 г. о пожаловании хиландарскому монастырю «места» Хрусии «єжє вь Пиягоү», что подкрепляет даже название этого документа ([8, № 109.19, 23, 24-25]; cp.: [8, c. 405]; также см.: [30, Append. III]; там же указана атрибуция и основная литература). Поистине, градостроительная деятельность Хиландаря по сооружению пиргов, выделяющаяся даже на фоне других афонских обителей, обладала не только оборонительной, но и культурной значимостью (подробнее см.: [6, с. 111 и дал., 141 и дал., 145 и дал., 184 и дал., 210 и дал., 231 и дал.; 1, с. 65 , $243,273]$; также см.: $[25$, с. $134,546-547])$. Безусловно, сведения о том касаются, прежде всего, строительства хиландарского пирга «на море», предназначенного для защиты от пиратов храма Спаса [8, № 99.25-37 и дал.]. Отмеченный факт, в частности, подтверждают три из четырех заметно различающихся рукописных версий хрисовула Стефана Уроша II Милутина 1303-1304 гг. и грамоты последующих лет (ср.: [8, № 104.A.163-164, 166-167 и дал., 172-173 и дал., 186-188, 204-206, 209-210, 212-216, 117 и дал., 229-230 и дал., 241-243; № 104.В.64-64, 67-68 и дал., 72-73 и дал., 85-86, 101-103, 106-107, 109-114, 114-115 и дал., 125-126 и дал., 136-137; № 104.Г.97-98, 99-100 и дал., 103 и дал.]; также см.: [8, № 121.A.25-26, 35, 36-39, 55-56, 60 и дал., 62-64 и дал., 66-67 и дал., 73-74 и дал.; № 121.Б.18-19, 28-29 и дал., 37 и дал.; № 122.А.5-6; № 122.Б.6; № 131.69-70; 
Ю.Я. Вин. Укрепленные села средневековой Византии: город или деревня?

№ 143.16-17,30-31 и дал.]). Объяснение тому, в общем-то говоря, лежит на поверхности: «пирги», «жилые башни» и тому подобные оборонительные сооружения в Средневековье становятся не просто общебалканским архитектурно-строительным компонентом, $a$, как показывает названный хиландарский пирг, социокультурным явлением. Именно это подчеркивает характеристика названного пирга: «стол'п вєлик и твљьды"! [8, № 121.А.25; № 121.Б.18-19] В пользу сказанного неоспоримым аргументом служат и прочие многократные свидетельства славянских актов, где там и здесь упоминаются «пирги» (напр., см.: [8, № 73.22-23; № 90.А.40; № 90.Б.39]). Более того, сведения о них достаточны для внесения коррективов в проделанные наблюдения над византийскими актами ([8, № 23.Б.46-48]; ср.: [8, № 23.A.B.39-42; 30, № 6.B.39-42]) и выявление аналогий ${ }^{3}$.

Результаты и Заключение. Общие закономерности. Таким образом, еще задолго до палеологовского периода сельские поселки в Византии начали обрастать башнями, стенами и уподоблялись крепостям, что вполне отвечает процессам, происходившим в Раннее и Развитое Средневековье во многих южных регионах Европы, где возведение укреплений, по сути превращающих село в крепость«каструм», становится правилом [64, p. 71, 180-181; 132, p. 105 etc.]. Обращаясь к ранее поднятой проблеме укрепления сельского поселения в Поздней Византии, необходимо принять во внимание более широкий взгляд на судьбы сельского селения в странах средневековой Европы, нежели простые заявления о встававших перед жителями сел оборонительных задачах. Достаточно вспомнить, что и в Средиземноморье Раннего Средневековья сельские поселения нередко окружали крепостные стены. По этому поводу Хр. Уикхэм, изучая сельские селения Западно-Римской империи раннесредневекового периода, подметил, что само сооружение вокруг них крепостных стен не означает превращения сел в городские центры, когда укрепления обладают только защитными, а не иными «публичными» функциями [151, p. 59]. И дело не в том, что в «центральный» период византийской истории, как бы скептически не относился к роли средневекового государства в организации оборонительной системы страны М. Уиттоу, большая часть крепостей-«каструм» принадлежала земельным магнатам и служила целям защиты их «домов» $[150$, p. 66 etc.]. Даже в таких условиях оборона поселков - вполне публичная задача. В конце концов, это подкрепляют многократные ссылки византийского законодательства на «кастра», которые, правда преимущественно сопоставлены «полису» или иным видам укреплений (напр., см.: NJ.128.C20 [70]; D.XLVII.22.001.Pr. [68] B.A.LX.32.001.Pr. [60]; CJ.VI.23.031.01 [69]B.A.XXXV.02.027.Pr. [57]; PT.XXXV.02.025. Pr. [157]; SB.Delta.13.030 [138]; PA.22.023 [129]). В любом случае средневековое византийское право, в сравнении с его древними прототипами, иногда с большей ясностью регламентирует размещение в крепостях воинов-«стратиотов» (напр., см.: D.XLVII.22.001.Pr. [68] - B.A.LX.32.001.Pr. [60]; D.XLI.03.004.Pr. [68] - B.A.L.03.004. Pr. [58]; D.XLVIII.05.016(15).03 [68] B.A.LX.37.016.03 [60]). Однако оборонительные функции сами по себе не видоизменяют статуса селения. При обсуждении проблем села в Средневековье прежде всего речь должна идти о возрастании ценности земли и обострении соперничества за нее между различными группами населения [74, p. 172 etc.].

А. Е. Лаиу в своем обобщении проблем развития византийского села, отмечая когерентность задач, решаемых медиевистами и византинистами в деле изучения строительства крепостей и укрепления селений в странах Западной Европы и Византии, в конечном итоге считает нужным подчеркнуть отличия этого процесса в Византии на протяжении от Раннего Средневековья к Поздней Византии. Независимо от того, насколько справедливы по существу суждения ученого о выявленных различиях, а именно небольших размерах большинства городских центров в раннесредневековой Византии и малого их влияния на село в условиях ведущей роли государства и правящих кругов господствующего класса, А. Е. Лаиу приходит к заключению о том, что и византийский город, и село видоизменялись (подробнее см.: [100, p. 36 etc., 53]). Нет сомнения в том, что в средневековой Византии и сопредельных с ней балканских странах, как показывает В. Кравари, строительство крепо- 


\section{ВИЗАНТИЙСКОЕ ОБЩЕСТВО И ГОСУДАРСТВО}

стей и даже простых укреплений в городах и сельских селениях становится тенденцией, обозначившей собою степень необходимой защиты для их жителей на примере развития северо-западного региона Македонии [98, p. 57 etc.]. Действительно, в ту эпоху каждая башня, судя по аргументам Ш. Джерстел, которая указывает на «турму» Китирион (Кๆти́рíov - sic!) на Крите, становилась оплотом для всех прилегающих к ней хорионов ([119, p. 435-436, № 7]; см.: [81, p. 25]). В любом случае, руины оборонительной башни в средневековом населенном пункте предполагают существование там в прошлом серьезного укрепленного поселения [81, p. 15-16, 20]. А само по себе воздвижение оборонительной башни и иных укреплений в сельском селении позволяет сопоставлять его в этом отношении с городским центром [81, p. 21-23]. Такого рода предположение может оказаться вполне оправданным, скажем, в отношении даже какой-либо «старой крепости»

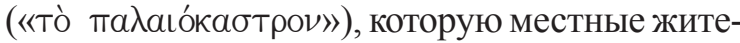
ли в округе, предположительно, Рентины [126, p. 235] обозначали по-славянски «Неволани»

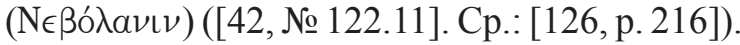

И потому вовсе не случайны примеры некоторых поздневизантийских сельских местностей и населенных пунктов, в том числе хорионов, для которых обозначение «кастрон» и его производные становятся названием. Ж. Лефор предполагает, что возникновение подобных топонимов обусловлено распространенностью лежащей в основе «реальности» (une realite frequente) $[105$, p. 100]. Так это было в катепаникии Ермилея, где известен соименный хорион «Кастрон» (напр., см.: [35, № 108.581-582, 585-587; № 109.489-496]; также см.: [35, Append. X.25-26, 28-29; 32, № 10.57]). Сходные проявления обнаруживали себя и в славянской топонимике, о чем можно судить на примере многократно упоминаемого в византийских документах хориона Кастрион («Кабтрі́о»») (напр., см.: [30, № 8.8-9 etc., 13-15; № 10.15-17; № 19.3-5 etc., 11-14; № 20.3-6 etc., 14-15 etc.; № 35.21-22]). У славян это село издавна известно ученым под названием Градец («Градєць») (напр., см.: $[14$, с. $54 ; 6$, с. 117-118, 217]). Без сомнения, оно восходит к топониму «Градац», который выступал фактически калькой греческого прототипа (о значении топонима «Градац» как указания на останки позднеантичных или раннесредневековых укреплений см.: [17, с. 124]). Славянский инвариант этого названия вошел в научный обиход вместе с переведенной на славянский язык поземельной описью рубежа XIII-XIV в. ([8, № 91]; ср.: [30, Append. II; 8, № 90.А.5-6, Б.5]), а также благодаря ряду ссылок на подобные тому славянские топонимы других населенных пунктов, включая города и села (напр., см.: [8, № 52.3, 18; № 54.31; № 64.47-48, 59, 63-64; № 125.31b, 33a]; также см.: [98, p. 38,39, n. $52,114,189])^{4}$.

Наряду с ним нельзя выпустить из поля зрения и топонимы, включающие обозначение «кастрон» в названии, образованном из словосочетания, или в наименовании сложного состава. Таково, скажем, название топотесии

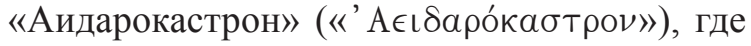
находилось имение Лавры Афанасия, расположенное близ хориона Принарион, которое в конце XIII в. было населено проскафименами ([35, № 79.12; № 89.97-101; № 105.4-5; № 112.36-37; 37, № 118.92-94]; также см.: [36, Append. XI.38-39]). И уж не счесть упоминаний в актах топонимов «Палеокастрон»

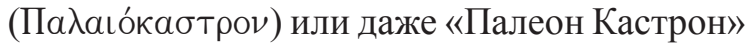

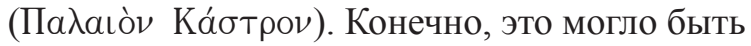
наименование какой-либо «старой» крепости, древней цитадели городского центра, где под тенью старых стен селились жители и заново теплилась жизнь (напр., см.: [36, № 139.45; 40, № 17.16; 31, № 21.93-94; № 25.22]). Но во многих случаях оно указывало не просто на заброшенное оборонительное сооружение. Скажем, в последней четверти XIV в. великий примикирий Иоанн, составляя свое завещание, описывает на острове Тасос дорогу, ведущую из «Верхней Крепости»

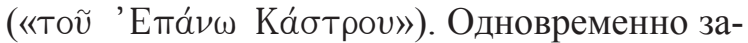
вещатель упоминает и о пролегавшей тут же

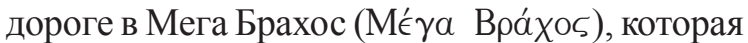
пересекала «Палеокастрон» [38, № 10.23-24]. Так обозначали, по всей вероятности, местности, названия коих сохраняли в веках память о разбросанных повсюду разрушенных крепостных укреплениях (напр., см.: [47, № 50.11, 50; № 53.193, 200; 48, № 70.192-193, 195-196; № 75.308-309; № 79.289, 290-291; 48, № 86.142-143, 144-145; 43, № 25.21-22; 38, № 10.23-24]). С ними допустимо сравнивать названия сельских поселков, в частности, «Па- 
леокастрон» близ Струмицы, который характеризуется как хорион (напр., см.: [48, № 56.6-8, 245-247; № 77.2-3, 7-8, 12, 14, 18, 23, 27, 29$30,34,37-38,41,43,46-47,50,53-54,55-56$, 63, 67-68, 79-80, 83-84, 88, 91, 93-94, 96-97, $107,110-111,111-112,123,135,141-142$, 146, 147-148, esp. 169-170, 189, 203-204]).

Словом, в Поздней Византии отсутствие пирга или крепостной стены вокруг села, будь то «коме» или «хорион», в рассматриваемый период воспринимается как отличительная, а не типичная черта (ср.: [91, p. 166.16-17]). И все-таки главное - не внешние перемены, а вопрос о структуре и особенностях сельского поселения средневековой Византии, составе его населения, административных функциях и экономике. Наконец, не могут быть сброшены со счетов вопросы о статусе сельских общин, социально-экономической и социокультурной роли общинного уклада в пригородных районах сельской местности, которые время от времени специалисты затрагивают напрямую в связи с укреплением как городов, так и сел. И хотя эти аспекты научных изысканий остались за рамками настоящего исследования, именно здесь находится ключ к решению проблемы различий между поздневизантийским городом и селом, даже если оно обрастало укреплениями.

\section{ПРИМЕЧАНИЯ}

${ }^{1}$ Например, см.: [154, б. 187-189; 88, p. 192; 101, p. 181]. Там же указана основная литература. Аналогичные выводы позволяли сделать раскопки средневековых поселений на территории, скажем, Румынии. Например, см.: [121, р. 1355-1356].

2 Проблема обозначений сельских поселений Византии требует отдельного освещения вне рамок настоящего исследования, поскольку она затрагивает целый ряд специальных аспектов, нуждающихся в обстоятельном обсуждении. Общая концепция и принципиальные суждения автора этих строк по поводу обозначения сельского поселения кратко изложены в тезисах выступления на конференции «Ранние этапы урбанизации». См.: [2, с. 47-51, особ. с. 47-49].

3 То же самое, что говорилось относительно византийских актов, можно повторить и относительно частично отличных друг от друга версий грамоты 1300 г. названного краля монастырю Св. Георгия в Скопье [8, № 92.Б.31-32, 34-35; № 92.В.10-11, 12, 35-36, 109-110]. Помимо про- чего, один из фрагментов этого документа касается укреплений в местечке Водене: здесь дважды наряду с одноименным «пиргом» приведены ссылки на «кулу», о которой говорится так, словно это два разных строения; причем «кула» охарактеризована как «грддни көүль», то есть она примыкает к какой-то «ограде», иначе - крепостной стене [8, № 92.В.90-91]. Избегая «домысливать» указанные отнюдь не технические детали, решение вопроса об укреплениях Водене автор этих строк оставляет специалистам. В то же время будет упущением не сопоставить славянскую версию указа кралицы Елены с его латинской копией (1276-1308 гг.), где упоминанию «кулы», стоявшей на поле села Заторцы под Катором соответствует латинское обозначение «in castelo», тем самым подкрепляя прежде сделанные на этот счет наблюдения над византийскими аналогиями (ср.: [8, № 110.А.12; № 110.Б.20]).

${ }^{4}$ Некоторые из славянских топонимов, допустим, название села «Градица» («Градицє») (подробнее см.: [18, с. 124-125]), были реципированы и воспроизводились в греческой транслитерации («Грабі́бта» и т. п.) (напр., см.: [35, № 72.41, 58; № 89.105; № 91.78-79, 212-241; № 109.697-737; 36, № 118.99; Append. XI.47]; также см.: [46, № 4.26, 38; 47, № 53.512; № 5.29-30; № 12.12; № 13.7-8; 42, № 97.21; № 108.32; Append. VI.25]).

\section{REFERENCES}

1. Bubalo Đ. Pisana reč u Srpskom Srednjem veku: znachaj $i$ upotreba pisanih dokumenata $u$ srednjovekovnom srpskom društvu [The Written Language in Serbian Moyen Age: The Significance and Use of Documents in the Mediaeval Serbian Society]. Belgrade, Stubi Kulture Publ. 2009. 358 p.

2. Vin Yu.Ya. Gorod ili derevnya? Ukreplennye sela srednevekovoy Vizantii [The Town or Country? The Fortified Village of the Mediaeval Byzantium]. Rannie etapy urbanizatsii. Vostochnaya Evropa $v$ Drevnosti i Srednevekove, XXXI Chteniya pamyati chl.korr. AN SSSR V.T. Pashuto. Moskva, 17-19 aprelya $2019 \mathrm{~g}$.: materialy conf. [Early Stages of Urbanization. East Europe in the Ancient Mediaeval History. XXXI Proceeding in Memoriam of Acad. AN SSSR V. T. Pashuto. Moscow, $17^{\text {th }}-19^{\text {th }}$ April 2019. Mat. of Conf.]. Moscow, IVI RAS Publ., 2019, pp. 47-51.

3. Solovjev A., Mošin V., eds. Grchke povelje srpskih vladara [The Greek Acts of Serbian Rulers]. Belgrade, Publ. of Nikole Krotić, 1936. CXXXII, 537 p.

4. Daskalova A., Rajkova M., eds. Gramoti na balgarskite tsare [The Acts of Bulgarian Tsars]. Sofia, Marin Drinov Publ., 2005. 448 p.

5. Bubalo Đ., ed. Dushanov zakonik [The Dušan's Law Code]. Belgrade, Zavod za učbenike, Službeni glasnik Publ., 2010. 243 p. 
6. Živojinović M. Istorija Khilandara: Od osnivanja manastira 1198. do 1335. godine [The History of Chilandar: From Foundation of the Monastery 1198 till 1335]. Belgrade, Prosveta Publ., $1998.306 \mathrm{p}$.

7. Živojinović M. Pirg [Pyrgos]. Ćirković S., Mihaljčić R., eds. Leksikon srpskog srednjeg veka [The Lexicon of Serbian Middle Ages]. Belgrade, Knowledge Publ., 1999. 513 p.

8. Mošin V., Ćirković S., Sindik D., eds. Zbornik srednjovekovnih ćirilichkikh povelja i picama Srbije, Bosne i Dubrovnika. Vol. 1. 1186-1321 [The Collection of Mediaeval Cyrillic Charters and Letters of Serbia, Bosnia and Dubrovnik. Vol. 1. 1186-1321]. Belgrade, Istorijski institut Publ., 2011. 652 p.

9. Ivanova Yu.V. Narodnoe zhilishche Gretsii [The Folk Dwelling of Greece]. Tipy selskogo zhilishcha v stranakh zarubezhnoy Evropy [The Types of Rural Dwelling in Countries of Foreign Europe]. Moscow, Nauka Publ., 1968, pp. 120-138.

10. Kilimnik E.V. Funktsii i sushchnost feodalnogo zamka v Evrope [The Functions and Essence of the Feudal Castle in Europe]. Istoricheskie, filisofskie, politicheskie i yuridicheskie nauki, kulturovedenie $i$ iskusstvovedenie. Voprosy teorii i praktiki [Historical, Philosophical, Political and Juridical Studies, Cultural Sciences and Art History. Question of the Theory and Practice], 2014, № 7-1 (45), pp. 68-72.

11. Maksimović Lj. Grad [Town]. Ćirković S., Mihaljčić R., eds. Leksikon srpskog srednjeg veka [The Lexicon of Serbian Middle Ages]. Belgrade, Knowledge Publ., 1999, pp. 122-124.

12. Moskvin A.G., Burygin S.M. Ostrova Gretsii: ot Rodosa do Korfu. Istoricheskiy putevoditel [The islands of Greece: From Rhodos to Korfu. Historical Guide]. Moscow, Veche Publ., 2013. $304 \mathrm{p}$.

13. Ostrogorsky G. Radolivo: selo svetogorskog manastira Ivirona [Radolivo: The Village of St. Mountain Monastery Iviron]. Zbornik radova Vizantološkog Instituta [The Collection of Works of Byzantine Institute], 1961, vol. 7, pp. 67-84.

14. Ostrogorsky G. Serska oblast posle Dušanove smrti [Serska Country after Dušanov's Death]. Beograd, Nauchno delo Publ., 1965. XII, 171 p.

15. Ostrogorsky G. Komitisa i svetogorski manastiri [Komitisa and the St. Mountain Monasteries]. Zbornik radova Vizantološkog Instituta [The Collection of Works of Byzantine Institute], 1971, vol. 13, pp. 221-256.

16. Popović M. Branić-kula [Branich-Kula]. Ćirković S., Mihaljčić R., eds. Leksikon srpskog srednjeg veka [The Lexicon of Serbian Middle Ages]. Belgrade, Knowledge Publ., 1999, pp. 62-63.

17. Popović M. Gradats [Township]. Ćirković S., Mihaljčić R., eds. Leksikon srpskog srednjeg veka
[The Lexicon of Serbian Middle Ages]. Belgrade, Knowledge Publ., 1999. 124 p.

18. Popović M. Gradište [The Site of Ancient Settlement]. Ćirković S., Mihaljčić R., eds. Leksikon srpskog srednjeg veka [The Lexicon of Serbian Middle Ages]. Belgrade, Knowledge Publ., 1999, pp. 124-125.

19. Popović M. Donžon [Donjon]. Ćirković S., Mihaljčić R., eds. Leksikon srpskog srednjeg veka [The Lexicon of Serbian Middle Ages]. Belgrade, Knowledge Publ., 1999. 164 p.

20. Popović M. Kula [The Kula]. Ćirković S., Mihaljčić R., eds. Leksikon srpskog srednjeg veka [The Lexicon of Serbian Middle Ages]. Belgrade, Knowledge Publ., 1999, pp. 350-352.

21. Radić R. Drugo lice Vizantije: nekoliko sporednih tema [Another Face of Byzantium: Some Additional Themes]. Belgrade, Evoluta Publ., 2014. $352 \mathrm{p}$.

22. Sreznevskiy I.I. Slovar drevnerusskogo yazyka [The Dictionary of Old Russian]. Moscow, Kniga Publ., 1989, vol. 1, pt. 1. IX p., 804 col.

23. Sreznevskiy I.I. Slovar drevnerusskogo yazyka [The Dictionary of Old Russian]. Moscow, Kniga Publ., 1989, vol. 1, pt. 2. 805-1420 col., 49 p.

24. Sreznevskiy I.I. Slovar drevnerusskogo yazyka [The Dictionary of Old Russian]. Moscow, Kniga Publ., 1989, vol. 2, pt. 1. XV p., 852 col.

25. Taranovski T. Istorija srpskog prava $u$ Nemanjićkoj državi [The History of Serbian Law in Nemanjić's State]. Belgrade, Služebni list SR Publ., $1996.805 \mathrm{p}$.

26. Arutyunova-Fidanyan V.A., ed. Tipik Grigoriya Pakuriana [The Typicon of Gregory Pakurian]. Erevan, AN ArmSSR Publ., 1978. 249 p.

27. Uspenskiy F.I., Beneshevich V.N. Vazelonskie acty. Materialy dlya istorii krestyanskogo $i$ monastyrskogo zemlevladeniya $v$ Vizantii XIII$X V$ vekov [The Acts of Vazelon. The Materials of the Peasant and Monastic Landownership in Byzantium $13^{\text {th }}-15^{\text {th }}$ C.]. Leningrad, GPB Publ., 1927. 124, CLII p.

28. Kharkhordin O.V. Respublika. Polnaya versiya [Respublica. The Full Version]. Saint Petersburg, EU in SPb. Publ., 2021. 208 p.

29. Miklosich F., Müller J., eds. Acta et diplomata graeca medii aevi sacra et profana. Vol. IV, T. 1. Vindobonae, Carolus Gerold, 1871. XIV, 441 p.

30. Zivojinovic M., Kravari V., Giros Chr., eds. Actes de Chilandar. Texte. Vol. 1. Paris, P. Lethielleux, 1998. XX, 363 p.

31. Oikonomidès N., ed. Actes de Dionysiou. Texte. Paris, P. Lethielleux, 1968. XI, 251 p.

32. Oikonomidès N., ed. Actes de Docheiariou. Texte. Paris, P. Lethielleux, 1984. XIV, 397 p.

33. Lemerle P., ed. Actes de Kutlumus. Texte. Paris, P. Lethielleux, 1988. X, 478 p. 
34. Lemerle P., Guillou A., Svoronos N., Papachryssanthou D., eds. Actes de Lavra. Texte. Vol. 1. Paris, P. Lethielleux, 1970. X, 447 p.

35. Lemerle P., Guillou A., Svoronos N., Papachryssanthou D., eds. Actes de Lavra. Texte. Vol. 2. Paris, P. Lethielleux, 1977. XVI, 316 p.

36. Lemerle P., Guillou A., Svoronos N., Papachryssanthou D., eds. Actes de Lavra. Texte. Vol. 3. Paris, P. Lethielleux, 1979. XX, 230 p.

37. Lemerle P., Guillou A., Svoronos N., Papachryssanthou D., eds. Actes de Lavra. Études historiques; Actes Serbes complements et index. Vol. IV. Paris, P. Lethielleux, 1982. XIV, 413 p.

38. Kravari V., ed. Actes de Pantocrator. Texte. Paris, P. Lethielleux, 1991. XVI, 232 p.

39. Papachryssanthou D., ed. Actes de Protaton. Texte. Paris, P. Lethielleux, 1986. XIV, 320 p.

40. Lemerle P., Dagron G., Cirkovic S., eds. Actes de Saint-Panteleèmôn. Texte. Paris, P. Lethielleux, 1982. XII, 238 p.

41. Bompaire J., Lefort J., Kravari V., Giros Chr., eds. Actes de Vatopedi. Texte. Vol. 1. Paris, P. Lethielleux, 2001. XX, 475 p.

42. Lefort J., Kravari V., Giros Chr., Smyrlis K., eds. Actes de Vatopedi. Texte. Vol. 2. Paris, P. Lethielleux, 2006. XVIII, 525 p.

43. Papachryssanthou D., ed. Actes de Xenophon.

Texte. Paris, P. Lethielleux, 1986. XVI, 399 p.

44. Bompaire J., ed. Actes de Xeropotamou. Texte.

Paris, P. Lethielleux, 1964. XIV, 298 p.

45. Lefort J., ed. Actes d'Esphigménou. Texte.

Paris, P. Lethielleux, 1973. XIV, 250 p.

46. Lefort J., Oikonomidès N., Papachryssanthou D., Metreveli H., eds. Actes d'Iviron. Texte. Vol. 1. Paris, P. Lethielleux, 1985. XIV, 318 p.

47. Lefort J., Oikonomidès N., Papachryssanthou D., Kravari V., Metreveli H., eds. Actes d'Iviron. Texte. Vol. 2. Paris, P. Lethielleux, 1990. XIV, 368 p.

48. Lefort J., Oikonomidès N., Papachryssanthou D., Kravari V., Metreveli H., eds. Actes d'Iviron. Texte.

Vol. 3. Paris, P. Lethielleux, 1994. XIV, 412 p.

49. Lefort J., Oikonomidès N., Papachryssanthou D., Kravari V., Metreveli H., eds. Actes d'Iviron. Texte. Vol. 4. Paris, P. Lethielleux, 1995. XII, 260 p.

50. Amouretti M.-C., Comet G. Hommes et techniques de l'Antiquité à la Renaissance. Paris, Armand Colin, 1993. 186 p.

51. Anderson W., Swaan W. Castles of Europe from Charlemagne to the Renaissance. New York, Random Nourse, 1970. 304 p.

52. Angold M. The Byzantine Empire: 1025 1204. A Political History. London, New York, 1984. $\mathrm{X}, 334 \mathrm{p}$.

53. Dölger F., ed. Aus den Schatzkammern des Heiligen Berges. Textband. München, Verl. Bisch. F. Bruckmann, 1948. 363 p.
54. Aydemir I. Les Defensis du Bosphore. Towers and Small Castles, 2009, vol. 63, pp. 91-100.

55. Bartusis M.C. The Late Byzantine Army. Arms and Society, 1204-1453, Philadelphia, Univ. of Pennsylvania Pr., 1992. XVIII, 438 p.

56. Bartusis M.C. The Land and Privilege in Byzantium. The Institution of Pronoia. Cambridge, Cambridge Univ. Pr., 2012. XLIV, 697 p.

57. Scheltema H.J., Wal N. van der, eds. Basilicorum Libri LX. Series A. Text. Vol. 5. Groningen, H.D. Tjeenk Willink B.V., Martinus Nijhoff B.V., 1967, pp. XIV, 1559-1944, III.

58. Scheltema H.J., Wal N. van der, eds. Basilicorum Libri LX. Series A. Text. Vol. 6. Groningen, H.D. Tjeenk Willink B.V., Martinus Nijhoff B.V., 1969, pp. XXVII, 1945-2430, III.

59. Scheltema H.J., Wal N. van der, eds. Basilicorum Libri LX. Series A. Text. Vol. 7. Groningen, H.D. Tjeenk Willink B.V.; Martinus Nijhoff B.V., 1974, pp. XXVII, 2435-2733, VII.

60. Scheltema H. J., Holwerda D., Wal N. van der, eds. Basilicorum Libri LX. Series A. Text. Vol. 8. Groningen, Bouma's Boekhus; Wolters Noordhoff, 1988, pp. XXV, 2435-3131, II.

61. Bazzana A. Les Structures: Fortification et Habitat. Castrum I. Habitats fortifiés et organization de l'espace en Méditerranée médiévale. Table ronde tenue à Lyon les 4 et 5 mai 1982. Vol. 1. Lyon, Maison de L'Oriente et Méditerranée Jean Pouilloux, 1983, pp. 161-175.

62. Bouras Ch. City and Village. Urban Design and Architecture. Jahrbuch der Österreichischen Byzantinistik, 1981, vol. 31/2, pp. 611-653.

63. Bouras Ch. Aspects Byzantine City, EighthFifteenth Centuries. Laiou A.E., ed. The Economic History of Byzantium. From the Seventh through the Fifteenth Century. Vol. 2. Washington, Dumbarton Oaks Center, 2002, pp. 497-528.

64. Bourin M., Durand R. Vivre au village au Moyen Âge. Les solidarités paysannes du $11^{e}$ au $13^{e}$ siècles. Paris, Messidor, Temps actuels, 1984. 258 p.

65. Castrum I. Habitats fortifiés et organization de l'espace en Méditerranée médiévale. Table ronde tenue à Lyon les 4 et 5 mai 1982. Vol. 1. Lyon, Maison de L'Oriente et Méditerranée Jean Pouilloux, 1983. $\mathrm{V}, 219 \mathrm{p}$.

66. Cheynet J.Cl. Fortune et puissance de l'aristocratie ( $\mathrm{X}^{\mathrm{e}}-\mathrm{XII}^{\mathrm{e}}$ siècle). Kravari V., Lefort J., Morrison C., eds. Homme et richesses dans l'Empire byzantine. Vol. 2. VIII ${ }^{e}-X V^{e}$ siècle. Paris, P. Lethielleux, 1991, pp. 199-213.

67. Christie N., Herold H. Introduction. Defining and Understanding Defended Settlements in Early Medieval Europe. Structures, Roles, Landscapes und Communites. Christie N., Herold H., eds. Fortified Settlements in Early Medieval Europe. Defended 
Communities of the $8^{\text {th }}-10^{\text {th }}$ Centuries. Oxford, Philadelphia, Oxbow books, 2016, pp. XXIV-XXXVIII. 68. Krueger P., Mommsen Th., Schoell R., Kroll G., eds. Corpus Iuris Civilis. Vol. 1. Digesta; Institutia. Berolini, Weidmann, 1954. XVIII, 957 p.

69. Krueger P., Mommsen Th., Schoell R., Kroll G., eds. Corpus Iuris Civilis. Vol. 2. Codex Iustinianus. Berolini, Weidmann, 1954. XXVIII, 513 p. 70. Krueger P., Mommsen Th., Schoell R., Kroll G., eds. Corpus Iuris Civilis. Vol. 3. Novellae. Berolini, Weidmann, 1954. XX, 813 p.

71. Cursente B. Les villages dans l'Occident médiéval $\left(\mathrm{IX}^{\mathrm{e}}-\mathrm{XIV}^{\mathrm{e}}\right.$ siècle). Lefort J., Morrison C., Sodini J. P. eds. Les villages dans l'Empire byzantin (IVe-XIV siècle). Paris, Lethielleux, 2005, pp. 71-88.

72. Dagron G. The Urban Economy, SeventhTwelfth Centuries. Laiou A.E., ed. The Economic History of Byzantium. From the Seventh Through the Fifteenth Century. Vol. 2. Washington, Dumbarton Oaks Center, 2002. pp. 393-461.

73. Decker M.J. The Byzantine Art of War. Yardley, Pennsylvania, Westholme Publishing, 2013. $230 \mathrm{p}$.

74. Contamine Ph., Bompaire M., Lebecq S., Sarrazin J.-L. L'économie médiévale. Paris, Armand Colin, 2004. 448 p.

75. Eideneier H. Ein byzantinisches Kalendergedicht in der Volkssprache. Ëllēnika, 1979, vol. 31, no. 2, pp. 368-419.

76. Ellenblum R. Crusader Castles and Modern Histories. Cambridge, Cambr. Univ. Pr., 2007. XII, $362 \mathrm{p}$.

77. Christie N., Herold H., eds. Fortified Settlements in Early Medieval Europe. Defended Communities of the $8^{\text {th }}-10^{\text {th }}$ Centuries. Oxford, Philadelphia, Oxbow Books, 2016. XXVIII, 339 p.

78. Foss C., Scott J.A. Sardis. Laiou A.E., ed. The Economic History of Byzantium. From the Seventh through the Fifteenth Century. Vol. 2. Washington, Dumbarton Oaks Center, 2002, pp. 615-622.

79. François V., Spieser J.M. Pottery and Glass in Byzantium. Laiou A.E., ed. The Economic History of Byzantium. From the Seventh Through the Fifteenth Century. Vol. 2. Washington, Dumbarton Oaks Center, 2002, pp. 593-609.

80. Frankopan P. Land and Power in the Middle and Later Period. Haldon J., ed. The Social History of Byzantium. Oxford, Wiley-Blackwell, 2009, pp. 112142.

81. Gerstel Sh.E.J. Rural Lives and Landscapes in Late Byzantium. Art, Archaeology, and Ethnography. Cambridge, Cambr. Univ. Pr., 2015. XVIII, 207 p.

82. Guichard P. Orient et Occident. Peuplement et Societe. Castrum I. Habitats fortifiés et organization de l'espace en Méditerranée médiévale. Table ronde tenue à Lyon les 4 et 5 mai 1982. Vol. 1. Lyon, Maison de l'Oriente et Méditerranée Jean Pouilloux, 1983, pp. 177-196.

83. Guillou A. La civilisation byzantine. Paris, Arthaud, 1974. 620 p.

84. Haldon J.F. Byzantium in the Seventh Century. The Transformation of a Culture. Cambridge, Cambr. Univ. Pr., 1997. XXVIII, 492 p.

85. Haldon J.F. The Idea of the Town in Byzantine Empire. Brogiolo G.P., Ward-Perkins Br., eds. The Idea and the Ideal of the Town Between the Late Antiquity and the Early Middle Ages. Leiden, Brill, 1999, pp. 1-23.

86. Haldon J. Warfare, State and Society in the Byzantine World, 560-1204. London, New York, Routledge, Taylor \& Francis Group, 1999. X, 389 p.

87. Haldon J.F. Die byzantinische Stadt - Verfall und Wiederaufleben vom 6. bis zum ausgehenden 11 . Jahrhundert. Daim F., Drauschke J., eds. Haldon J. et al. Hinter den Mauern und auf dem offenen Land. Leben im Byzantinischen Reich. Mainz, Verl. d. RömischGermanischen Zentralmuseums, 2016, pp. 9-21.

88. Harvey A. Economic Expansion in Byzantine Empire, 900-1200. Cambridge, Cambr. Univ. Pr., 1989. XX, 298 p.

89. Hetherington P. Byzantine and Medieval Greece. Churches, Castles, and Art of the Mainland and Peloponnese. London, J. Murray, 1991. XVIII, 238 p., 16 pl.

90. Daim F., Drauschke J., eds. Hinter den Mauern und auf dem offenen Land, Leben im Byzantinischen Reich. Mainz, Verl. d. Römisch-Germanischen Zentralmuseums, 2016. 239 p.

91. Schopen L., ed. Ioannis Cantacuzeni, eximperatoris Historiarum libri IV. Vol. 1. Bonnae, Ed. Weberi, 1828. XXVI, 560 p.

92. Schopen L., ed. Ioannis Cantacuzeni, eximperatoris Historiarum libri IV. Vol. 2. Bonnae, Ed. Weberi, 1831. VIII, 615 p.

93. Jacobs I. "Urbanised" Villages in Early Byzantium. An Overview. Böhlenddorf-Arslan B., Schick R., eds. Transformation of City and Countryside in the Byzantine Period. Mainz, Verl. d. RömischGermanischen Zentralmuseums, 2020, pp. 13-23.

94. Kaplan P. Les hommes et terre à Byzance du VIe au XIe siècle. Propriete et exploitation du sol. Paris, Publ. de la Sorbonne, 1992. XL, 630 p.

95. Kaplan P. The Producing Population. Haldon J., ed. The Social History of Byzantium. Oxford, WileyBlackwell, 2009, pp. 143-167.

96. Kazanaki-Lappa M. Medieval Athens. Laiou A.E., ed. The Economic History of Byzantium. From the Seventh Through the Fifteenth Century. Vol. 2. Washington, Dumbarton Oaks Center, 2002,pp. 639-646.

97. Koder J. The Byzantiner. Kultur und Alltag im Mittelalter. Wien, Köln, Weimar, Böhlau Verl., 2016. $291 \mathrm{p}$. 
98. Kravari V. Villes et villages de Macédoine occidentale. Paris, P. Lethielleux, 1989. 409 p., 10 cart.

99. Kyriakidis S. Warfare in Late Byzantium, 1204-1453. Leiden, Boston, Brill, 2011. XXII, 254 p.

100. Laiou A.E. The Byzantine Village $\left(5^{\text {th }}\right.$ $14^{\text {th }}$ Century). Lefort J. et al., eds. Les villages dans l'Empire byzantin. $I V^{E}-X V^{E}$ siècle. Paris, Lethielleux, 2005, pp. 31-54.

101. Laiou A.E., Morrisson C. The Byzantine Economy. Cambridge, Cambr. Univ. Pr., 2007. 270 p.

102. Darko E., ed. Laonici Chalcocandylae Historiarum Demonstrationes. Vol. 2. Budapestini, Sumptibus Acad. Litterarum Hungaricae, 1927. 364 p.

103. Lawrence T.E. Crusader Castles. A New Edition with Introduction and Notes by D. Pringle. Oxford, Clarendon Pr., 1988. XL, 154 p.

104. Lefort J. Le cadastre de Radolibos (1103). Les géomètres et leurs mathématiques. Travaux et mémoires, 1981, vol. 8, pp. 269-313.

105. Lefort J. Habitat fortifiés en Macédoine orientale au Moyen Âge, Castrum I. Habitats fortifiés et organization de l'espace en Méditerranée médiévale. Table ronde tenue à Lyon les 4 et 5 mai 1982. Vol. 1. Lyon, Maison de l'Oriente et Méditerranée Jean Pouilloux, 1983, pp. 99-103.

106. Lefort J. Population et peuplement en Macédoine orientale, $\mathrm{XI}^{\mathrm{e}}-\mathrm{XV}^{\mathrm{e}}$ siècle. Kravari V., Lefort J., Morrison C., eds. Homme et richesses dans l'Empire byzantine. Vol. 2. Paris, P. Lethielleux, 1991, pp. 63-82.

107. Lefort J. The Rural Economy, SeventhTwelfth Centuries. Laiou A.E., ed. The Economic History of Byzantium. From the Seventh Through the Fifteenth Century. Vol. 1. Washington, DOC, 2002, pp. 231-310.

108. Lefort J. Les villages de Macédoine orientale en Moyen Âge ( $\mathrm{X}^{\mathrm{e}}-\mathrm{XIV}^{\mathrm{e}}$ siècle). Lefort J., Morrison C., Sodini J. P., eds. Les villages dans l'Empire byzantin (IV $V^{E}$-XIV siècle). Paris, Lethielleux, 2005, pp. 290-299.

109. Lefort J., Martin J. M. Fortifications et Pouvoirs en Méditerranée (X ${ }^{\mathrm{ème}}-\mathrm{XII}^{\mathrm{ème}}$ siècles). Castrum I. Habitats fortifiés et organization de l'espace en Méditerranée médiévale. Table ronde tenue à Lyon les 4 et 5 mai 1982. Vol. 1. Lyon, Maison de L'Oriente et Méditerranée Jean Pouilloux, 1983, pp. 197-207.

110. Lefort J., Martin J.M. L'organisation de l'espace rural: Macédoine et Italie du Sud ( $\mathrm{X}^{\mathrm{e}}$ XIII ${ }^{\mathrm{e}}$ siècle). Kravari V., Lefort J., Morrisson C., eds. Homme et richesses dans l'Empire byzantine. Vol. 2. Paris, P. Lethielleux, 1991, pp. 11-62.

111. Guillou A., ed. Les archives de SaintJean Prodrome sur le mont Ménécée. Paris, Press universitaires de France, 1955. 220 p.

112. Le typicon du monastère de Notre-Dame tes Bebaias Elpidos. Delehaye H., ed. Deux typica byzantins de l'époque des Paléologues. Bruxelles,
M. Hayez, Imprimeur de l'Académie Royale de Belgique, 1921, pp. 18-105.

113. Lilie R.J. Die ökonomische Bedeutung der Byzantinischen Provinzstadt (8.-12. Jahrhundert) im Spiegel der literarischen Quellen. Daim F., Drauschke J., eds. Hinter den Mauern und auf dem offenen Land. Leben im Byzantinischen Reich. Mainz, Verl. d. RömischGermanischen Zentralmuseums, 2016, pp. 55-62.

114. Marrindin G.E. Turris. Smith W., Wayte W., Marindin G.E., eds. A Dictionary of Greek and Roman Antiquities. Vol. 2. London, John Murray, 1891, pp. 907-909.

115. Martin J.M. Rapport. Kravari V., Lefort J., Morrison C., eds. Homme et richesses dans l'Empire byzantine. Vol. 2. Paris, P. Lethielleux, 1991, pp. 83-89.

116. Martin J.M., Noye Gh. Les villes de l'Italie byzantine ( $\mathrm{IX}^{\mathrm{e}}-\mathrm{XI}^{\mathrm{e}}$ siècle). Kravari V., Lefort J., Morrison C., eds. Homme et richesses dans l'Empire byzantine. Vol. 2. Paris, P. Lethielleux, 1991, pp. 27-62.

117. Martin J.M., Noye Gh. Les villages de l'Italie méridionale byzantine. Lefort J., Morrison C., Sodini J. P., eds. Les Villages dans l'Empire byzantin (IV -XIV siècle). Paris, Lethielleux, 2005, pp. 148-164.

118. Matschke K.P. Fortschritt und Reaktion in Byzanz im 14. Jahrhundert: Konstantinopel in der Bürgerkriegsperiode von 1341 bis 1354. Berlin, Akad. Verl., 1971. 264 p.

119. Gerola G., ed. Monumenti veneti nell'isola di Creta. Vol. 4. Venice, Instituto Veneto di Scienze, 1932. XII, $626 \mathrm{p}$.

120. Morrison C., Sodini J. P. The Sixth-Century Economy. Laiou A.E., ed. The Economic History of Byzantium. From the Seventh through the Fifteenth Century. Vol. 1. Washington, Dumbarton Oaks Center, 2002, pp. 171-220.

121. Neagu N. Colocviul. Arheologia aşezărilor rurale din secolele XII-XIV pe teritoriul României. Revista de Istorie, 1979, vol. 32, no. 7, pp. 1355-1356.

122. Noye Gh. Types et typologie de habitat fortifiés. Castrum I. Habitats fortifiés et organization de l'espace en Méditerranée médiévale. Table ronde tenue à Lyon les 4 et 5 mai 1982. Vol. 1. Lyon, Maison de l'Orient et Méditerranée Jean Pouilloux, 1983, pp. 121-143.

123. Oikonomidès N. À propos des armées des premiers Paléologues et des compagnies de Soldats. Travaux et mémoires, 1981, vol. 8, pp. 353-371.

124. Oikonomides N. The Contents of the Byzantine House from the Eleventh to the Fifteenth Century. Oikonomides N. Social and Economic Life in Byzantium. Alderschot, Ashgate, 2004, pp. 205-214.

125. Papachryssanthou D. Histoire d'un evêche byzantin. Hierissos en Chalcidique. Travaux et mémoires, 1981, vol. 1, pp. 373-396.

126. Bellier P., Bondoux R.-C., Cheynet J.C., Lefort J. eds. Paysages de Macédoine, leurs caractères, 


\section{ВИЗАНТИЙСКОЕ ОБЩЕСТВО И ГОСУДАРСТВО}

leur évolution à travers les documents et les récits des voyageurs. Paris, De Boccard, 1986. XIV, 315 p.

127. Perbellini G. The Polysemic Meaning of the Tower. From Defence to Symbol. Towers and Small Castles, 2009, vol. 63, pp. 7-18.

128. Pringle D. Introduction. Lawrence T.E. Crusader Castles. A New Edition with Introduction and Notes by D. Pringle. Oxford, Clarendon Pr., 1988, pp. XXI-XL.

129. Prochiron auctum. Zachariae a Lingenthal C.E., ed. Jus graeco-romanum. Pars VI. Lipsiae, Typ. J.B. Hirschfeld, 1870. VII, 439 p.

130. Wirth G., ed. Procopii Caesariensis De Aedificius Libri VI. Haury J., ed. Procopii Caesariensis Opera omnia. Vol.IV.Lipsiae, Teubneri, 1964. XII, 409 p.

131. Grecu V., ed. Pseudo-Phrantzes. Macarie Melissenos. Chronica (1258-1481). Grecu V., ed. Georgios Sphrantzes, Memorii 1401-1477. Bucureşti, Editura Acad., 1966, pp. 149-590.

132. Reynolds S. Kingdoms and Communities in Western Europe. 900-1300. Oxford, Clarendon Press, 1984. IX, 387 p.

133. Rheidt K. The Urban Economy of Pergamon. Laiou A.E., ed. The Economic History of Byzantium. From the Seventh Through the Fifteenth Century. Vol. 2. Washington, Dumbarton Oaks Center, 2002, pp. 623-629.

134. Schreiner P. Das Haus in Byzanz nach den schreiftlichen Quellen. Mit einem Exkurs über Häuserpreise. Beck H., Steuer H., eds. Haus und Hof in ur- und frühgeschichtlicher Zeit. Göttingen, Vandenhoeck \& Ruprecht, 1997, pp. 277-320.

135. Smyrlis K. Estate Fortification in Late Byzantine Macedonia. The Athonite Evidence. Daim F., Drauschke J., eds. Hinter den Mauern und auf dem offenen Land. Leben im Byzantinischen Reich. Mainz, Verl. d. Römisch-Germanischen Zentralmuseums, 2016, pp. 189-205.

136. Steriotou I. The Small «Regional» Castles in the Countryside of the Island of Crete During the Venetian Dominion. Towers and Small Castles, 2009, vol. 63 , pp. 101-114.

137. Synopsis Basilicorum minor. Zachariae a Lingenthal C.E., ed. Jus graeco-romanum. Pars II. Lipsiae, Typ. T.O. Wegel, 1856, pp. 9-264.

138. Synopsis Basilicorum. Zachariae a Lingenthal C.E., ed. Jus graeco-romanum. Pars $V$. Lipsiae, Typ. J.B. Hirschfeld, 1870, pp. 3-705.

139. Kazhdan A.P., ed. The Oxford Dictionary of Byzantium. Vol. 2. New York, Oxford, Oxford Univ. Pr., 1991. XXXIII, 729-1474 p.

140. Kazhdan A.P., ed. The Oxford Dictionary of Byzantium. Vol. 3. New York, Oxford, Oxford Univ. Pr., 1991. XXXIII, 1475-2232 p.

141. Haldon J., ed. The Social History of Byzantium. Oxford, Wiley-Blackwell, 2009. XXVII, 300 p.
142. Toubert P. Byzantium and the Mediterranean Agrarian Civilization. Laiou A.E., ed. The Economic History of Byzantium. From the Seventh Through the Fifteenth Century. Vol. 1. Washington, Dumbarton Oaks Center, 2002, pp. 377-391.

143. Böhlenddorf-Arslan B., Schick R., eds. Transformation of City and Countryside in the Byzantine Period. Mainz, Verl. d. Römisch-Germanischen Zentralmuseums, 2020. 148 p.

144. Typicon Gregorii Pacuriani. Kaukhchishvili S.G., ed. Svedeniya vizantiyskikh pisateley o Gruzii [Information of Byzantine Writers About Georgia]. Vol. 5. Tbilisi, Izd-vo AN GruzSSR Publ., 1963, pp. 97-301.

145. Veikou M. "Rural Towns" and "In-Between" or "Third" Spaces: Settlement Patterns in Byzantine Epirus $\left(7^{\text {th }}-11^{\text {th }}\right.$ Centuries) from an Interdisciplinary Approach. Archeologia Medievale, 2009, vol. 36, pp. 43-54.

146. Veikou M. Urban or Rural? Theoretical Remarks on the Settlement Patterns in Byzantine Epirus $\left(7^{\text {th }}-11^{\text {th }}\right.$ Centuries). Byzantinische Zeitschrift, 2010, vol. 103, no. 1, pp. 171-193.

147. Veikou M. Byzantine Histories, Settlement Stories. Kastra, "Isles of Refuge", and "Unspecified Settlements" As In-Between or Third Spaces. Preliminary Remarks on Aspects of Byzantine Settlement in Greece $\left(6^{\text {th }}-10^{\text {th }}\right.$ C. $)$. Kioussopoulou T., ed. Oi Byzantines poles, 8os-15os aiōnas. Prooptikēs tēs ereunas kai nees ermēneutikes proseggineis [Byzantine Cities, $8^{\text {th }}-15^{\text {th }}$ Centuries. Prospects of Research and New Interpretative Approaches]. Rethymno, Ekd. Philosophikēs Scholēs Panepist. Kritēs Publ., 2012, pp. 159-206.

148. Veikou M. Settlement in Greek Countryside from the $4^{\text {th }}$ to $9^{\text {th }}$ Centuries. Forms et Patterns. Antiquite Tardive, Revue intern. d'histoire et archeologie (IVVIII ${ }^{e}$ s.), 2014, vol. 21, pp. 127-133.

149. Volk R. Gesundheitswesen und Wohltätigkeit im Spiegel der Byzantinischen klostertypika. München, Institut für Byzantinistik und neugriechische Philologie der Universität, 1983. LXXX, 326 p.

150. Whittow M. Rural Fortification in Western Europe and Byzantium, Tenth to Twelfth Century. Efthymiadis S., Rapp C., Tsougarakis D., ed. Bosporos - Court, City and Country in Byzantium. Essay in Honour of Cyril Mango. Amsterdam, A.M. Hakkert, 1995, pp. 59-74.

151. Wickham Chr. The Development of Villages in the West, 300-900. Lefort J. et al., eds. Les Villages dans L'Empire Byzantin, IV $-X V^{e}$ siècle. Paris, Lethielleux, 2005, pp. 55-69.

152. Archim. Ierōnymos Delēmarēs, ed. Apanta Iōannou Apokaukou. Syllogē tōn mechri sēmera diasōthentōn keimenōn tou epiphanous kai logiou Mètropolitou Naupaktou kai Artēs Iōannou Apokaukou 
(arches 13ou aiōnos) [Complete Works of John Apokaukos. Collection of the Surviving Texts of the Eminent and Learned Metropolitan of Nafpaktos and Arta John Apokaukos (Early $13^{\text {th }}$ Century)]. Nafpaktos, Adelphotes Metamorphōseōs tou Sōtēros Naupaktou Publ., 2000. 497 p.

153. Gasparēs Ch. $\bar{E}$ gē kai oi agrotes stē Mesaiōnikē Krētēe, 13os-14os ai. [Land and Peasants in Medieval Crete, $13^{\text {th }}-14^{\text {th }}$ C. $]$. Athens, EIE, Institouto Byzantinōn Ereunōn Publ., 1997. 463 p.

154. Guillou A., Mavromatis L. Mesaionike archaiologia, Epistemonike synastese sto Palermo (Septembrios 1974) [Mediaeval Archaeology, the Scientific Meeting in Palermo (September 1974)]. Byzantina, 1976, vol. 8, pp. 185-189.

155. Koukoules $\mathrm{Ph}$. Byzantinōn bios kai politismos [The Life and Civilization of the Byzantines]. Vol. 4. Athens, Institut Francais d'Athènes, 1951. 499 p.

156. Laiou-Thomadakis A.E. Koinōnia kai oikonomia (1204-1453) [Society and Economy (1204-1453)]. Istoria tou Ellēnikou Ethnous [History of the Greek Nation]. Vol. 9. Athens, Ekdotikē Athenōn Publ., 1979, pp. 214-243.

157. Hoermann S., Stepski-Doliwa N., de, Seidl E., eds. M. Kritou tou Patze Tipoukeitos, sive Librorum LX Basilicorum Summarium. In 5 Vols. Vol. 3. Roma, Città del Vaticano, Bibliotheca Apostolica Vaticana, 1983. XLIV, 338 p.

158. Hoermann S., Stepski-Doliwa N. de, Seidl E., eds. M. Kritou tou Patze Tipoukeitos, sive Librorum LX Basilicorum Summarium. In 5 Vols. Vol. 4. Roma, Città del Vaticano, Bibliotheca Apostolica Vaticana, 1987. XXIV, 287 p.

159. Rallēs G.A., Potlēs M., eds. Syntagma tōn Theiōn kai Ierōn Kanonōn [Syntagma of the Divine and Sacred Canons]. In 6 Vols. Vol. 1. Athens, Ek tēs typograph. G. Chartophylakos Publ., 1852. 20, 403 p.

160. Tzannetatos Th.S. To praktikon tēs Latinikēs episkopēs Kefallēnias tou 1264 kai è epitomē autou: Kritikē ekdosis autōn [Praktikon of the Latin Diocese of Kephallenia of 1264 and Its Epitome: Critical Edition]. Athens, Dōdōnē Publ., 1965. 183 p.

\section{Information About the Author}

Yury Ya. Vin, Candidate of Sciences (History), Senior Researcher, Institute of World History, Russian Academy of Sciences, Prosp. Leninskiy, 32a, 991119 Moscow, Russian Federation, hkn@igh.ras.ru, https://orcid.org/0000-0001-9904-4123

\section{Информация об авторе}

Юрий Яковлевич Вин, кандидат исторических наук, старший научный сотрудник, Институт всеобщей истории РАН, Ленинский просп., 32а, 991119 г. Москва, Российская Федерация, hkn@igh.ras.ru, https://orcid.org/0000-0001-9904-4123 